OECD Economics Department Working Papers No. 1224

Finance and income inequality in OECD

countries
Oliver Denk, Boris Cournède 
Organisation de Coopération et de Développement Économiques

Organisation for Economic Co-operation and Development

16-Jun-2015

ECONOMICS DEPARTMENT

English - Or. English

\section{FINANCE AND INCOME INEQUALITY IN OECD COUNTRIES}

ECONOMICS DEPARTMENT WORKING PAPERS No. 1224

By Oliver Denk and Boris Cournède

OECD Working Papers should not be reported as representing the official views of the OECD or of its member countries. The opinions expressed and arguments employed are those of the author(s).

Authorised for publication by Jean-Luc Schneider, Deputy Director, Policy Studies Branch, Economics Department.

All Economics Department Working Papers are available at www.oecd.org/eco/workingpapers

JT03378730

Complete document available on OLIS in its original format

This document and any map included herein are without prejudice to the status of or sovereignty over any territory, to the delimitation of international frontiers and boundaries and to the name of any territory, city or area. 
OECD Working Papers should not be reported as representing the official views of the OECD or of its member countries. The opinions expressed and arguments employed are those of the author(s).

Working Papers describe preliminary results or research in progress by the author(s) and are published to stimulate discussion on a broad range of issues on which the OECD works.

Comment on the Papers is invited, and may be sent to OECD Economics Department, 2 rue André Pascal, 75775 Paris Cedex 16, France, or by e-mail to eco.contact@oecd.org.

The statistical data for Israel are supplied by and under the responsibility of the relevant Israeli authorities. The use of such data by the OECD is without prejudice to the status of the Golan Heights, East Jerusalem and Israeli settlements in the West Bank under the terms of international law.

\section{(C) OECD (2015)}

You can copy, download or print OECD content for your own use, and you can include excerpts from OECD publications, databases and multimedia products in your own documents, presentations, blogs, websites and teaching materials, provided that suitable acknowledgment of OECD as source and copyright owner is given. All requests for commercial use and translation rights should be submitted to rights@oecd.org 


\section{ABSTRACT/RÉSUMÉ}

\section{Finance and income inequality in OECD countries}

Using data from OECD countries over the past three decades, this paper shows that financial expansion has fuelled greater income inequality. Higher levels of credit intermediation and stock markets are both related with a more unequal distribution of income. Greater income inequality may not reduce the welfare of even the lowest earners so long as their income growth is not negatively affected. Numerical simulations based on a novel empirical methodology indicate, however, that the financial expansion has put a brake on the income growth of many low- and middle-income households. No evidence is found that financial crises explain the observed relationships. While causality is difficult to establish beyond doubt, the paper finds credit patterns which are inconsistent with reverse causality running from greater income inequality to more household borrowing.

JEL classification: D14; D63; E21; E51; G01; G2.

Keywords: Finance, income inequality, Gini coefficient, income growth, OECD countries, intermediated credit, stock market, financial crisis, income decile.

\section{Finance et les inégalités de revenus dans les pays de l'OCDE}

Ce document, qui s'appuie sur des données portant sur les trente dernières années recueillies dans des pays de l'OCDE, démontre que l'expansion financière a contribué à creuser les inégalités de revenus. La progression de l'intermédiation du crédit et le développement des marchés boursiers sont tous deux corrélés à une répartition plus inégale des revenus. Cette hausse des inégalités de revenus ne nuit pas nécessairement au bien-être des travailleurs, y compris des moins bien rémunérés, pour autant qu'elle n'ait pas d'impact négatif sur la croissance de leurs revenus. Des simulations numériques, réalisées selon une méthodologie empirique novatrice, montrent toutefois que l'expansion financière a entravé la hausse des revenus de nombreux ménages à revenus faibles ou intermédiaires. Rien n'indique que les crises financières puissent expliquer les corrélations observées. S'il est difficile d'établir avec certitude un lien de causalité, le document identifie des caractéristiques de la répartition du crédit parmi la population qui tendent à exclure l'hypothèse de causalité inverse, selon laquelle une plus grande inégalité des revenus entraînerait une hausse de l'emprunt chez les ménages.

Classification JEL : D14 ; D63 ; E21 ; E51 ; G01 ; G2.

Mots-clés : Finance, inégalité de revenus, coefficient de Gini, croissance des revenus, pays de l'OCDE, intermédiation du crédit, marché boursier, crise financière, décile de revenu. 


\section{TABLE OF CONTENTS}

FINANCE AND INCOME INEQUALITY IN OECD COUNTRIES ......................................................

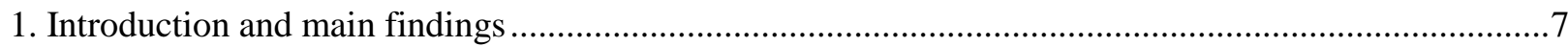

2. The empirical relationship between finance and income inequality ................................................

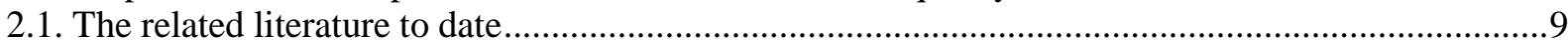

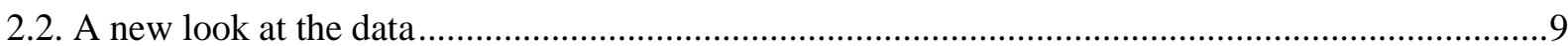

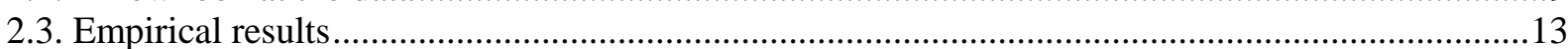

3. Examining causality in the negative relationship between credit and income equality .......................19

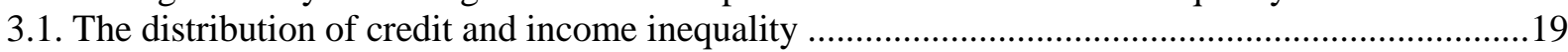

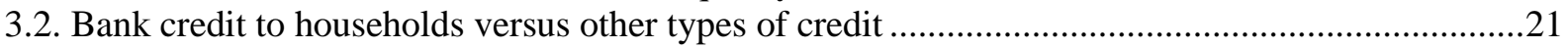

4. Finance and household income growth across the income distribution...............................................22

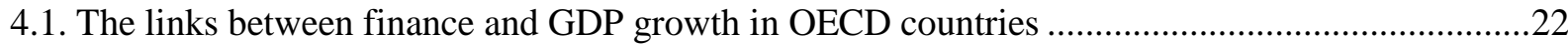

4.2. The links between finance and household income growth in OECD countries ..............................25

4.3. Quantifying the overall association between finance and household income growth .....................29

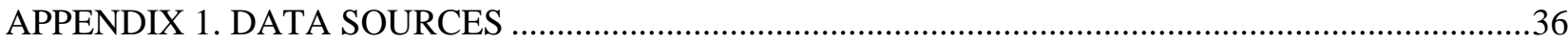

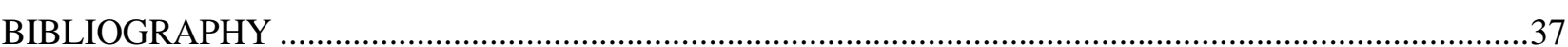

\section{Tables}

1. The relationship between the value added of finance and income inequality .....................................14

2. The relationship between intermediated credit and income inequality..............................................15

3. The relationship between stock market capitalisation and income inequality ....................................16

4. The role of the labour share for the finance and inequality relationship ............................................18

5. The relationship between the value added of finance and household income growth

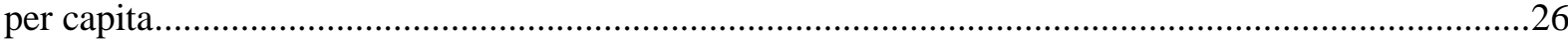

6. The relationship between intermediated credit and household income growth per capita ...................27

7. The relationship between stock market capitalisation and household income growth per capita.

\section{Figures}

1. The bivariate relationship between the value added of finance and income inequality

2. The bivariate relationship between intermediated credit and income inequality..................................11

3. The bivariate relationship between stock market capitalisation and income inequality .......................11

4. Distribution of household credit across income groups and income inequality ..................................20

5. Credit-to-income ratio across income groups and income inequality .................................................21

6. The bivariate relationship between the value added of finance and household income growth............23

7. The bivariate relationship between intermediated credit and household income growth .....................24

8. The bivariate relationship between stock market capitalisation and household income growth ...........24

9. Income shares of different income deciles and income inequality ...................................................30

10. Changes in household income growth for different income deciles from an expansion of intermediated credit by $10 \%$ of GDP

11. Changes in household income growth for different income deciles from an expansion of stock market capitalisation by $10 \%$ of GDP... 
12. Changes in household income growth for different income deciles from an expansion of intermediated credit by $10 \%$ of GDP (alternative approach)

13. Changes in household income growth for different income deciles from an expansion of stock market capitalisation by $10 \%$ of GDP (alternative approach)

Box

Box 1. The approach to estimate the relationship between finance and income growth across the distribution. 
ECO/WKP(2015)42 
ECO/WKP(2015)42

\title{
FINANCE AND INCOME INEQUALITY IN OECD COUNTRIES
}

\author{
Oliver Denk and Boris Cournède ${ }^{1}$
}

\section{Introduction and main findings}

1. The global financial crisis, with its large losses in output and employment, has raised questions about the influence of finance on the distribution of income and the inclusiveness of growth. Financial firms pay very high remuneration, and measures of financial size, such as credit intermediation or stock markets, have increased very strongly during past decades. This financial expansion has taken place in a period over which income inequality has widened in many countries and real incomes of households, especially of the socially vulnerable, have often been stagnant.

2. Using data from OECD countries over the past three decades, this paper analyses the relationship between finance and income inequality in the population as a whole, and between finance and income growth of households at different levels of income. Based on panel data econometrics, it investigates the extent to which the phenomena of expanding finance, rising income inequality and slowing income growth are directly related, rather than a reflection of coinciding trends. The empirical associations with income inequality and income growth are studied for three measures of financial size: $i$ ) the value added of finance, $i$ ) credit by banks and other financial institutions to the non-financial private sector (henceforth called intermediated credit), and iii) stock market capitalisation, in each case relative to GDP.

3. Against the existing literature on inequality and the role of finance, the main contributions of the paper are threefold. First, the focus is on the influence of finance on the distribution of income and income growth in advanced countries, where inequality can be measured in a more harmonised way across countries. Second, the paper develops a novel empirical methodology that combines inequality and growth considerations to determine heterogeneous estimates of structural changes in the economy on the income growth of households with different incomes. The methodology is applied to the context of finance, but it could similarly be used to study public policies in other areas. Third, new evidence from the euro area sheds light on the possibility of reverse causality between finance and income inequality, namely that a more unequal income distribution may lead to a higher demand for credit.

1. Economics Department, OECD. Corresponding author: Oliver Denk (email: Oliver.Denk@ oecd.org). This paper is part of the OECD project on "Finance and Inclusive Growth" that was prepared for the Working Party No. 1 of the Economic Policy Committee. It benefited from helpful contributions by Alexandre Cazenave-Lacroutz. We are grateful to Federico Cingano, Peter Hoeller, Christian Kastrop, Nicolas Ruiz, Sebastian Schich, Jean-Luc Schneider, Gert Wehinger, members of the Working Party No. 1 of the Economic Policy Committee and participants to a seminar on New Approaches to Economic Challenges for valuable comments and suggestions. Thanks go to Celia Rutkoski for technical assistance. 


\section{ECO/WKP(2015)42}

4. The two core findings of the paper are:

- More finance has, on average across countries and at the levels observed over past decades, been associated with higher income inequality. This relationship holds when intermediated credit and stock market capitalisation are used to measure the size of finance. No relationship is detected for the value added of finance. The econometric links for the credit and stock market measures of finance with income inequality hold relative to a country's average level of finance and its trend.

- Higher income inequality associated with financial expansion may not reduce the welfare of even the poorest so long as their income growth is not negatively affected. Numerical simulations indicate, however, that the rise of finance has put a brake on the income growth of many low-and middle-income households. This is particularly the case for intermediated credit, and also, although to a lesser extent, for stock market capitalisation.

5. When exploring the mechanisms behind the negative relationship between finance and income equality, the following two transmission channels are rejected by the data:

- Financial crises are unlikely to be the main explanatory factor for the observed relationships: The links between finance and inequality also hold in periods without financial crises, and inequality usually does not rise during financial crisis periods.

- Results from two complementary empirical approaches are inconsistent with reverse causality going from higher income inequality to more demand for, or supply of, intermediated credit:

- Data from euro area countries indicate that borrowing by households at the lower end of the income distribution is not relatively higher in countries with higher income inequality. ${ }^{2}$

- The association between credit and inequality is not tighter for bank credit to households than other types of lending.

6. Therefore, alternative transmission channels must be at work that link more finance with higher inequality. Empirical evidence from two companion papers (Denk, 2015; Denk and Cazenave-Lacroutz, 2015) indicates that this is both the direct result of financial sector earnings and the indirect result of forces in the credit and stock markets. Financial sector employees are very strongly concentrated at the top of the income distribution, and their earnings exceed those of employees with similar profiles (such as age, gender or education) in other sectors. In addition, the distribution of household credit and household wealth is even more unequal than the distribution of income. Back-of-the-envelope calculations suggest that high and dispersed financial sector pay explains about half of the estimate for the overall relationship between finance and inequality.

7. The rest of the paper is organised as follows. The next section describes the data and examines the overall relationship of finance with income inequality in OECD countries. Section 3 investigates the possibility of reverse causality from higher income inequality to more credit. Using a novel empirical methodology, Section 4 simulates heterogeneous estimates for the link between finance and the income growth of households at different points in the distribution.

2. The household-level data used come from the Eurosystem Household Finance and Consumption Survey. The results published and the related observations and analysis may not correspond to results or analysis of the data producers. 


\section{The empirical relationship between finance and income inequality}

8. OECD countries have witnessed an increase in income inequality (Braconier et al., 2014; OECD, 2008, 2011, 2015) and a sharp expansion of finance (Cournède et al., 2015) over the past three decades. This section studies empirically the extent to which the two phenomena are directly related, rather than a reflection of coinciding trends. It first provides an overview of the current state of knowledge on finance and inequality. It then turns to the descriptive statistics and estimation strategy. The final part reports the empirical results for three measures of financial size: the value added of finance, intermediated credit and stock market capitalisation.

\subsection{The related literature to date}

9. Theoretical research has remained inconclusive about the distributional consequences of finance (for summaries, see Beck, 2012; Demirgüç-Kunt and Levine, 2009). On the one hand, more finance may make it easier for poorer individuals to borrow for viable projects, which would have the effect of reducing income inequality (Aghion and Bolton, 1997; Galor and Moav, 2004; Galor and Zeira, 1993). On the other hand, improvements in the formal financial sector could be more likely to benefit the well-off who rely less on informal connections for capital (Greenwood and Jovanovic, 1990). This argument will be weakened if, for example, a larger formal financial sector pulls more segments of the population into the formal labour market. Other authors have argued that financial innovation, asymmetric compensation schemes for bank managers, a concentrated banking system and bailout expectations can encourage risk-taking and benefit the financial sector at the expense of the rest of the economy (Korinek and Kreamer, 2014).

10. Empirical research has similarly not been overly firm on the sign of the overall link between finance and income inequality. In large samples of developed, middle-income and developing economies, countries with higher levels of financial development have been found to experience faster reductions in income inequality and poverty in some studies (Beck et al., 2007; Clarke et al., 2006). Other studies have obtained the opposite result. These include Jauch and Watzka (2012), and Gimet and Lagoarde-Segot (2011) who, relying on a structural vector autoregressive model, conclude that higher bank credit tends to increase income inequality in a sample of 49 mostly advanced and middle-income countries. Fournier and Koske (2012) find in a large micro-data set covering many OECD countries that a greater share of financial activities in GDP usually translates into greater earnings dispersion, driven by the high end of the income distribution. Bahmani-Oskooee and Zhang (2015) argue that in most countries where finance has an equalising effect on the income distribution the improvement is only temporary.

11. Several studies have considered the impact of bank regulation on the distribution of income. For example, Delis et al. (2014) argue that liberalisation of international capital flows and of credit and interest rate controls decrease income inequality, while the opposite is the case for liberalisation of securities markets. In addition, evidence indicates that the relaxation of bank branching restrictions in the United States reduced inequality by boosting incomes in the lower part of the distribution (Beck et al., 2010). By contrast, Claessens and Perotti (2007) stress that financial liberalisation, aimed at facilitating access to financial services, may in practice raise inequality due to regulatory capture.

\subsection{A new look at the data}

12. The conjecture that more finance reduces income inequality by providing poor households with loan and saving instruments seems especially compelling for lower-income countries. This channel appears less relevant for advanced countries, where it contrasts with the popular perception that a growing financial sector has contributed to the long-term increase in income inequality. In revisiting these relationships, this paper uses the Gini coefficient for disposable income, i.e. income after taxes and transfers, of householdequivalised units to measure income inequality. The Gini coefficient is a widely used concept which has 
the benefit of expressing the overall degree of inequality across the income distribution in a single number. This ranges from 0 (perfect equality) to 1 (perfect inequality).

13. The data cover nearly all OECD countries during 1974-2011, although due to substantial data gaps the average number of observations per country is around ten. ${ }^{3}$ The measures of finance studied are the value added of finance, intermediated credit and stock market capitalisation, each divided by GDP. Appendix 1 describes the data sources for this paper. A first glance at the data reveals a positive correlation of income inequality with the value added of finance, intermediated credit and stock market capitalisation (Figures 1-3). To remove the possible bias from persistent cross-country differences, the three measures of finance and the Gini coefficient are demeaned by their respective average for each country. The relationship with the Gini coefficient is somewhat tighter for intermediated credit and stock market capitalisation than for the value added of finance.

Figure 1. The bivariate relationship between the value added of finance and income inequality

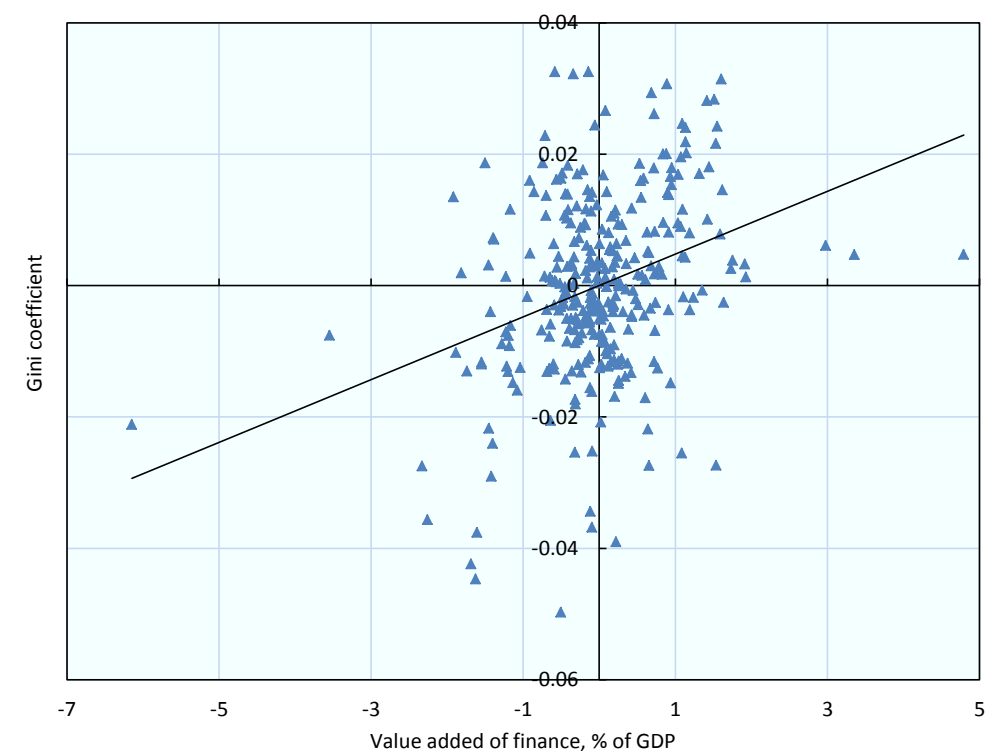

Note: The data cover 31 OECD countries between 1974 and 2011 . Value added of finance is financial and insurance activities. The Gini coefficient is based on household disposable income adjusted for household size. The line indicates the fitted values from an OLS regression through the data points. The two variables are demeaned using each country's mean to average out differences between countries that are persistent over time.

Source: OECD Structural Analysis database; OECD Income Distribution and Poverty database; OECD Secretariat calculations.

3. The data for the Gini coefficient exclude observations from nine countries before a break occurred in these countries' series. Alternative samples that treat these observations as nine different countries yield coefficient estimates the statistical significance of which is in some instances a little less than of those presented here. This is related to the small number of observations per country before a break occurred in the series. 
ECO/WKP(2015)42

Figure 2. The bivariate relationship between intermediated credit and income inequality

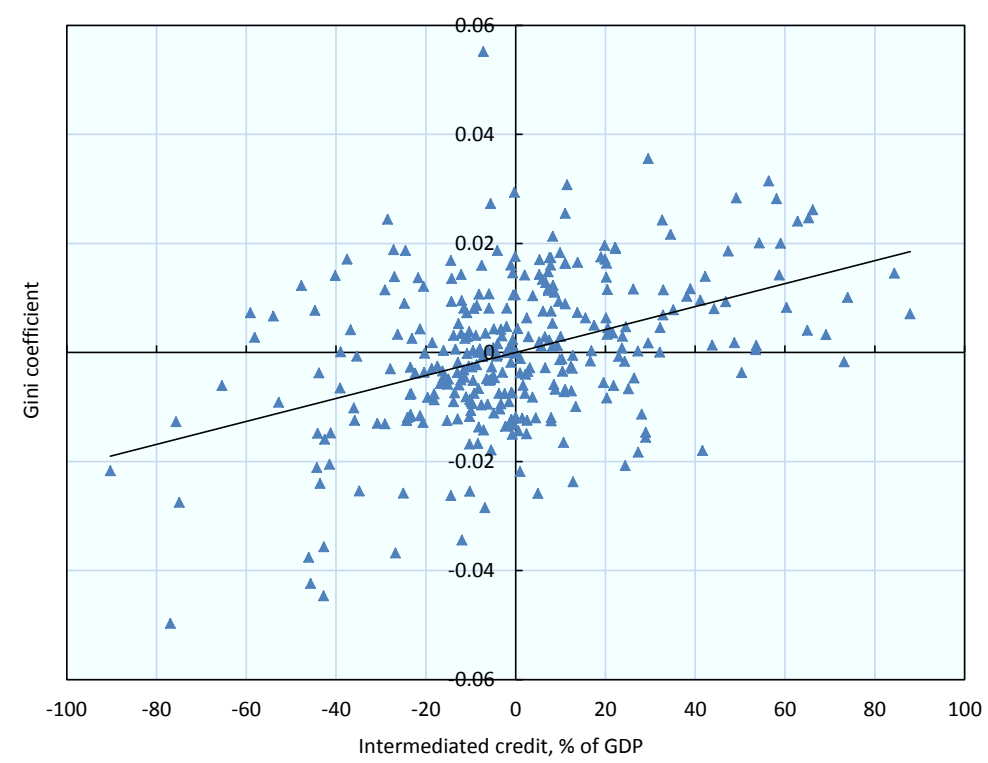

Note: The data cover 33 OECD countries between 1974 and 2011. Intermediated credit is credit to the non-financial private sector by financial institutions. The Gini coefficient is based on household disposable income adjusted for household size. The line indicates the fitted values from an OLS regression through the data points. The two variables are demeaned using each country's mean to average out differences between countries that are persistent over time.

Source: World Bank Global Financial Development database; Bank for International Settlements credit series; Statistics Canada; OECD Income Distribution and Poverty database; OECD Secretariat calculations.

Figure 3. The bivariate relationship between stock market capitalisation and income inequality

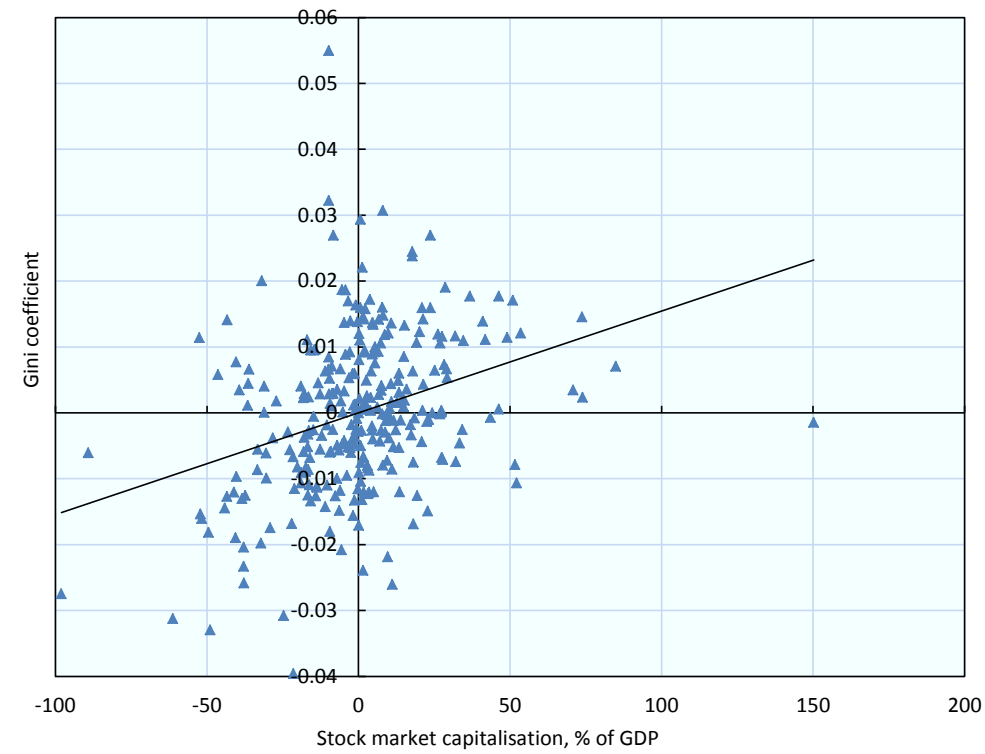

Note: The data cover 33 OECD countries between 1989 and 2011. Stock market capitalisation is the value of all shares listed in a stock market. The Gini coefficient is based on household disposable income adjusted for household size. The line indicates the fitted values from an OLS regression through the data points. The two variables are demeaned using each country's mean to average out differences between countries that are persistent over time.

Source: World Bank Global Financial Development database; OECD Income Distribution and Poverty database; OECD Secretariat calculations. 
14. The correlations reported so far could be due to finance and income inequality having increased in tandem over past decades for idiosyncratic reasons. The following econometric analysis investigates the degree to which these links remain after accounting for time trends and other possibly confounding factors. The baseline specification is:

$$
\operatorname{Gini}_{c t}=\beta \text { Fin }_{c t}+x_{c t} \gamma+\rho_{c}+\tau_{t}+\varphi_{c} t+\varepsilon_{c t} .
$$

The parameter of interest is the coefficient $\beta$ representing the conditional correlation of the Gini coefficient with the chosen measure of finance, Fin $_{c t}$ : the value added of finance, intermediated credit or stock market capitalisation. $c$ and $t$ are indices for country and year. Standard errors are clustered at the country-level to account for heteroscedasticity and autocorrelation in the error term for observations from the same country (Angrist and Pischke, 2009; Liang and Zeger, 1986). With a few countries contributing a relatively large proportion to the overall sample size, the statistical significance of the regression results is in some cases reduced when observations from such a country are dropped.

15. The baseline specification controls for other determinants of income inequality, $x_{c t}$, often used in the literature, including past OECD reports. They are: the unemployment rate (to account for businesscycle fluctuations in the Gini coefficient), the level of skills proxied by the average number of school years in the adult population, and openness to trade (defined as the ratio of exports and imports to GDP). $\rho_{c}$ are country fixed effects, which capture country specificities that are persistent over time, and $\tau_{t}$ are year fixed effects, which pick up OECD-wide shocks to income inequality. The set of country-specific coefficients $\varphi_{c}$ on the linear time trend $t$ controls for the trend increase in the Gini coefficient that has been observed in several countries. It therefore helps avoid identifying a potentially spurious correlation with the concomitant rise of finance. Alternatively, as in Braconier and Ruiz-Valenzuela (2014), the countryspecific linear time trends can be interpreted as accounting for skill-biased technological change. Results are also reported when year fixed effects and linear time trends are excluded. The idiosyncratic disturbances are denoted by $\varepsilon_{c t}$.

16. The estimation strategy comes with two caveats. The first is on the interpretation of the parameter $\beta$. As was mentioned, many countries experienced a long-term increase in finance over the sample period. The effect of this rise is absorbed in the country-specific linear time trends and also the year fixed effects which account for all year-to-year changes that are common across countries. As a result, the inclusion of linear time trends and year fixed effects means that the correlation between finance and income inequality is identified in relative, not absolute terms. The parameter $\beta$ in Equation 1 captures the relationship between changes in the size of finance and changes in the Gini coefficient in one country relative to others. The same applies to all differences-in-differences specifications which typically do not estimate the average influence of the variable of interest.

17. The second caveat is that this set of regressions is not conclusive about the direction of causation. The inclusion of linear time trends and year fixed effects reduces one source of potential endogeneity: the long-term increase in inequality and finance in many countries. Furthermore, country fixed effects remove omitted variables bias related with country specificities that do not vary over time. However, this does not rule out reverse causation or the presence of other confounding factors. To illustrate with one example: a positive association between intermediated credit and the Gini coefficient can be interpreted as too much private sector debt raising income inequality. But an alternative interpretation could be that when inequality is high low-income households demand more credit to reduce their consumption disparities with high-income households. Such issues of causality are discussed in the next section. 


\subsection{Empirical results}

18. The value added of finance has no discernible empirical association with income equality in most specifications (Table 1). Column 1 correlates value added with the Gini coefficient accounting for country fixed effects and thus reproduces the positive relationship depicted in Figure 1. The coefficient, however, halves and becomes statistically insignificant when the unemployment rate, school years and trade openness are controlled for (Column 2). Including year fixed effects reduces the coefficient to 0 (Column 3), suggesting that the positive correlation in the first two columns is due to the common longterm trend component in the value added of finance and Gini coefficient. Column 4, which is the baseline specification (Equation 1), adds country-specific linear time trends in an even stronger test to weed out spurious long-run correlations and again finds no evidence of a link between the value added of finance and inequality.

19. A different picture emerges when intermediated credit is used to measure financial size (Table 2). In this case, the positive association identified in Figure 2 and reproduced in Column 1 continues to hold when the unemployment rate, school years, trade openness (Column 2) and year fixed effects (Column 3) are added. The estimate from the baseline specification (Equation 1), which includes country-specific linear time trends, is of similar size as those in the previous columns and statistically significant at the $10 \%$ level (Column 4). On the face of it, its economic significance appears small: an increase in intermediated credit by $10 \%$ of GDP is associated with an increase in the Gini coefficient by 0.13 Gini points. ${ }^{4}$ However, Section 4 illustrates that such a rise of the Gini coefficient translates into substantial changes in disposable income growth at different points in the distribution.

20. The relationship of income inequality with stock market capitalisation (Table 3 ) is essentially the same as with intermediated credit. The coefficient is positive and statistically significant at conventional levels in all specifications (Columns 1-4). A 10\% of GDP increase in stock market capitalisation in the baseline specification with linear time trends is associated with an increase in the Gini coefficient by 0.11 Gini points. As for intermediated credit, Section 4 shows that such a rise of the Gini coefficient can imply substantial changes in disposable income growth at different points in the distribution. When the three measures of finance are jointly included in the baseline specification, the coefficients on intermediated credit and stock market capitalisation (but not the one on the value added of finance) are positive and significant at the 5\% level (not shown). Few of the control variables in Tables 1-3 display statistical significance. The number of school years exhibits a significantly positive link with income inequality in several specifications, ${ }^{5}$ and the unemployment rate is also positively related with income inequality in a few cases.

4. The standard deviation of intermediated credit is $11 \frac{1}{2}$ per cent of GDP after controlling for exogenous covariates, country fixed effects, year fixed effects and country-specific linear time trends.

5. In a survey of the existing literature on education and income inequality, Abdullah et al. (2014) find that somewhat more than half of all empirical estimates indicate a positive relationship. 
Table 1. The relationship between the value added of finance and income inequality

\begin{tabular}{|c|c|c|c|c|c|c|}
\hline \multirow[t]{2}{*}{ Dependent variable: } & \multicolumn{6}{|c|}{ Gini coefficient } \\
\hline & (1) & $(2)$ & $(3)$ & $(4)$ & $(5)$ & $(6)$ \\
\hline Value added of finance & $\begin{array}{l}0.480^{\star *} \\
(0.226)\end{array}$ & $\begin{array}{c}0.244 \\
(0.186)\end{array}$ & $\begin{array}{l}-0.010 \\
(0.133)\end{array}$ & $\begin{array}{c}0.027 \\
(0.133)\end{array}$ & $\begin{array}{c}0.017 \\
(0.175)\end{array}$ & $\begin{array}{c}0.027 \\
(0.135)\end{array}$ \\
\hline Unemployment rate & - & $\begin{array}{c}0.024 \\
(0.060)\end{array}$ & $\begin{array}{c}0.085 \\
(0.060)\end{array}$ & $\begin{array}{l}0.053 \\
(0.075)\end{array}$ & $\begin{array}{c}-0.074 \\
(0.087)\end{array}$ & $\begin{array}{c}0.052 \\
(0.077)\end{array}$ \\
\hline School years & - & $\begin{array}{c}1.160^{\star * *} \\
(0.254)\end{array}$ & $\begin{array}{c}0.035 \\
(0.280)\end{array}$ & $\begin{array}{l}1.212^{* *} \\
(0.465)\end{array}$ & $\begin{array}{l}1.573^{\star *} \\
(0.667)\end{array}$ & $\begin{array}{l}1.220^{\star *} \\
(0.472)\end{array}$ \\
\hline Trade openness & - & $\begin{array}{c}-0.007 \\
(0.012)\end{array}$ & $\begin{array}{l}-0.009 \\
(0.011)\end{array}$ & $\begin{array}{c}0.004 \\
(0.013)\end{array}$ & $\begin{array}{l}-0.001 \\
(0.021)\end{array}$ & $\begin{array}{c}0.005 \\
(0.013)\end{array}$ \\
\hline Banking crisis dummy & - & - & - & - & - & $\begin{array}{c}0.033 \\
(0.329)\end{array}$ \\
\hline Year fixed effects & No & No & Yes & Yes & Yes & Yes \\
\hline Linear country trends & No & No & No & Yes & Yes & Yes \\
\hline R-squared & 0.937 & 0.951 & 0.965 & 0.980 & 0.986 & 0.980 \\
\hline Sample period & $1974-2011$ & $1974-2011$ & $1974-2011$ & $1974-2011$ & 1974-2006 & $1974-2011$ \\
\hline Observations & 318 & 317 & 317 & 317 & 212 & 317 \\
\hline
\end{tabular}

Note: All regressions are OLS and include country fixed effects. Standard errors, which are shown in brackets, are clustered at the country-level. ${ }^{* * *}$ indicates significance at the $1 \%$ level, ${ }^{* *}$ at the $5 \%$ level and ${ }^{*}$ at the $10 \%$ level. The Gini coefficient is expressed in Gini points and based on household disposable income adjusted for household size. Value added of finance is financial and insurance activities divided by GDP, school years is average years of schooling in the population aged 25 and over, and trade openness is the sum of exports and imports divided by GDP. The sample covers 31 OECD countries.

Source: OECD Secretariat calculations using OECD Structural Analysis database; OECD Income Distribution and Poverty database; OECD Economic Outlook database; R. J. Barro and J. W. Lee (2013), "A New Data Set of Educational Attainment in the World, 1950-2010", Journal of Development Economics, 104, pp. 184-198; L. Laeven and F. Valencia (2013), "Systemic Banking Crises Database", IMF Economic Review, 61(2), pp. 225-270. 
Table 2. The relationship between intermediated credit and income inequality

\begin{tabular}{|c|c|c|c|c|c|c|}
\hline \multirow[t]{2}{*}{ Dependent variable: } & \multicolumn{6}{|c|}{ Gini coefficient } \\
\hline & (1) & (2) & (3) & (4) & (5) & (6) \\
\hline Intermediated credit & $\begin{array}{l}0.019^{* *} \\
(0.008)\end{array}$ & $\begin{array}{l}0.013^{*} \\
(0.007)\end{array}$ & $\begin{array}{l}0.011^{*} \\
(0.006)\end{array}$ & $\begin{array}{l}0.013^{*} \\
(0.007)\end{array}$ & $\begin{array}{c}-0.0003 \\
(0.016)\end{array}$ & $\begin{array}{l}0.014^{*} \\
(0.007)\end{array}$ \\
\hline Unemployment rate & - & $\begin{array}{c}-0.003 \\
(0.054)\end{array}$ & $\begin{array}{c}0.007 \\
(0.068)\end{array}$ & $\begin{array}{c}0.025 \\
(0.078)\end{array}$ & $\begin{array}{c}-0.125 \\
(0.106)\end{array}$ & $\begin{array}{c}0.028 \\
(0.082)\end{array}$ \\
\hline School years & - & $\begin{array}{c}0.904^{* * *} \\
(0.254)\end{array}$ & $\begin{array}{c}0.294 \\
(0.276)\end{array}$ & $\begin{array}{c}1.397^{* * *} \\
(0.501)\end{array}$ & $\begin{array}{l}1.363^{* *} \\
(0.643)\end{array}$ & $\begin{array}{l}1.371^{* *} \\
(0.508)\end{array}$ \\
\hline Trade openness & - & $\begin{array}{l}-0.005 \\
(0.010)\end{array}$ & $\begin{array}{l}-0.006 \\
(0.009)\end{array}$ & $\begin{array}{c}0.008 \\
(0.012)\end{array}$ & $\begin{array}{r}-0.0004 \\
(0.019)\end{array}$ & $\begin{array}{c}0.008 \\
(0.012)\end{array}$ \\
\hline Banking crisis dummy & - & - & - & - & - & $\begin{array}{l}-0.098 \\
(0.314)\end{array}$ \\
\hline Year fixed effects & No & No & Yes & Yes & Yes & Yes \\
\hline Linear country trends & No & No & No & Yes & Yes & Yes \\
\hline R-squared & 0.928 & 0.947 & 0.961 & 0.979 & 0.985 & 0.979 \\
\hline Sample period & $1974-2011$ & $1974-2011$ & $1974-2011$ & $1974-2011$ & $1974-2006$ & $1974-2011$ \\
\hline Observations & 324 & 316 & 316 & 316 & 217 & 316 \\
\hline
\end{tabular}

Note: All regressions are OLS and include country fixed effects. Standard errors, which are shown in brackets, are clustered at the country-level. *** indicates significance at the $1 \%$ level, ** at the $5 \%$ level and * at the $10 \%$ level. The Gini coefficient is expressed in Gini points and based on household disposable income adjusted for household size. Intermediated openness is the sum of exports and imports divided by GDP. The sample covers 32 GED countries.

Source: OECD Secretariat calculations using World Bank Global Financial Development database; Bank for International Settlements credit series; Statistics Canada; OECD Income Distribution and Poverty database; OECD Economic Outlook database; R. J. Barro and J. W. Lee (2013), "A New Data Set of Educational Attainment in the World, 1950-2010", Journal of Development Economics, 104, pp. 184-198; L. Laeven and F. Valencia (2013), "Systemic Banking Crises Database", IMF Economic Review, 61(2), pp. 225-270. 
Table 3. The relationship between stock market capitalisation and income inequality

\begin{tabular}{|c|c|c|c|c|c|c|}
\hline \multirow[t]{2}{*}{ Dependent variable: } & \multicolumn{6}{|c|}{ Gini coefficient } \\
\hline & (1) & $(2)$ & (3) & $(4)$ & (5) & (6) \\
\hline Stock market capitalisation & $\begin{array}{c}0.016^{\star * *} \\
(0.005)\end{array}$ & $\begin{array}{c}0.014^{* * *} \\
(0.005)\end{array}$ & $\begin{array}{l}0.014^{\star *} \\
(0.005)\end{array}$ & $\begin{array}{l}0.011^{*} \\
(0.006)\end{array}$ & $\begin{array}{c}0.004 \\
(0.005)\end{array}$ & $\begin{array}{l}0.012^{*} \\
(0.006)\end{array}$ \\
\hline Unemployment rate & - & $\begin{array}{c}0.061 \\
(0.073)\end{array}$ & $\begin{array}{c}0.051 \\
(0.082)\end{array}$ & $\begin{array}{l}0.151^{* *} \\
(0.071)\end{array}$ & $\begin{array}{c}0.042 \\
(0.145)\end{array}$ & $\begin{array}{l}0.143^{*} \\
(0.073)\end{array}$ \\
\hline School years & - & $\begin{array}{l}0.537^{*} \\
(0.313)\end{array}$ & $\begin{array}{c}0.039 \\
(0.395)\end{array}$ & $\begin{array}{c}0.376 \\
(0.532)\end{array}$ & $\begin{array}{c}0.167 \\
(0.863)\end{array}$ & $\begin{array}{c}0.466 \\
(0.552)\end{array}$ \\
\hline Trade openness & - & $\begin{array}{l}-0.001 \\
(0.011)\end{array}$ & $\begin{array}{c}-0.0002 \\
(0.010)\end{array}$ & $\begin{array}{c}0.015 \\
(0.011)\end{array}$ & $\begin{array}{c}0.005 \\
(0.018)\end{array}$ & $\begin{array}{c}0.016 \\
(0.010)\end{array}$ \\
\hline Banking crisis dummy & - & - & - & - & - & $\begin{array}{c}0.377 \\
(0.324)\end{array}$ \\
\hline Year fixed effects & No & No & Yes & Yes & Yes & Yes \\
\hline Linear country trends & No & No & No & Yes & Yes & Yes \\
\hline R-squared & 0.950 & 0.953 & 0.961 & 0.984 & 0.991 & 0.984 \\
\hline Sample period & $1989-2011$ & $1989-2011$ & $1989-2011$ & $1989-2011$ & $1989-2006$ & $1989-2011$ \\
\hline Observations & 290 & 287 & 287 & 287 & 178 & 287 \\
\hline
\end{tabular}

Note: All regressions are OLS and include country fixed effects. Standard errors, which are shown in brackets, are clustered at the country-level. *** indicates significance at the $1 \%$ level, ** at the $5 \%$ level and * at the $10 \%$ level. The Gini coefficient is expressed in Gini points and based on household disposable income adjusted for household size. Stock market (

Source: OECD Secretariat calculations using World Bank Global Financial Development database; OECD Income Distribution and Poverty database; OECD Economic Outlook database; R. J. Barro and J. W. Lee (2013), "A New Data Set of Educational Attainment in the World, 1950-2010", Journal of Development Economics, 104, pp. 184-198; L. Laeven and F. Valencia (2013), "Systemic Banking Crises Database", IMF Economic Review, 61(2), pp. 225-270. 
21. Several mechanisms could explain the estimated relationships of finance with income inequality. Three of them are explored in the remainder of this paper. First, the Gini coefficient may rise in periods of financial crises. Second, more intermediated credit and larger stock markets, relative to GDP, could be correlated with a greater share of income going to capital. Third, there might be reverse causality from greater income inequality to more demand for, or supply of, intermediated credit. However, no evidence is found in support of any of these mechanisms. Therefore, alternative transmission channels must be at work linking more finance with higher inequality. As was mentioned above, many of them have been empirically tested in two companion papers: Denk (2015) and Denk and Cazenave-Lacroutz (2015).

22. For example, insofar as financial sector workers are located at the top of the income distribution, this concentration could link higher financial sector employment with lower income equality. Additional channels are related with the large implicit public subsidies that financial institutions receive (Admati and Hellwig, 2013; Schich et al., 2014; Schich and Lindh, 2012; Ueda and Weder di Mauro, 2013). Denk et al. (2015) argue that, when such subsidies are combined with competitive barriers in the financial sector labour market and strong competition in the credit market, they can distribute inefficient rents to workers and consumers of financial firms. Financial rents in the form of excessively high financial sector earnings and underpricing of credit risk may benefit especially well-payed individuals.

23. Extensions of the baseline specification (Equation 1) serve to investigate whether the negative links between finance and income equality are due to financial crises. Column 5 in Tables 1-3 restricts the sample up to 2006, before the global financial crisis, and Column 6 introduces an indicator variable for financial crisis years, as defined by Laeven and Valencia (2013). The coefficients on all three measures of finance become smaller and are statistically insignificant when the global financial crisis is excluded from the sample. But this is likely related to the reduction of the sample by one third. In the more sophisticated tests which control for years with a financial crisis, the coefficients on finance are very similar to those in the baseline specification. The financial crisis dummy itself is not a statistically significant determinant of disposable income inequality, in line with the descriptive evidence from the global financial crisis (OECD, 2013). While this does not rule out longer-term consequences of financial crises for income inequality, it suggests that financial crises are unlikely to be the main explanatory factor for the observed relationship between finance and inequality.

24. Another concern is that more intermediated credit and larger stock markets, relative to GDP, may be correlated with a greater share of income going to capital. Financial expansion could then seem to reinforce income inequality merely because of its statistical association with rising wealth, which is even more unequally distributed than income (Piketty, 2014). Regressions have been run adding the labour share as a control to check this hypothesis (Table 4). Extending the analysis in this way reduces the sample size by one quarter, and this reduction in sample size has the effect that the coefficient of interest in the baseline regressions is no longer statistically significant (Columns 1, 3 and 5). Adding the labour share to the specification does not change the results beyond the effect due to the sample-size reduction (Columns 2, 4 and 6). The labour share itself is not statistically related with the Gini coefficient. 
Table 4. The role of the labour share for the finance and inequality relationship

\begin{tabular}{|c|c|c|c|c|c|c|}
\hline \multirow{3}{*}{$\begin{array}{l}\text { Dependent variable: } \\
\text { Measure of finance: }\end{array}$} & \multicolumn{6}{|c|}{ Gini coefficient } \\
\hline & \multicolumn{2}{|c|}{ Value added of finance } & \multicolumn{2}{|c|}{ Intermediated credit } & \multicolumn{2}{|c|}{ Stock market capitalisation } \\
\hline & $(1)$ & $(2)$ & (3) & $(4)$ & (5) & $(6)$ \\
\hline Measure of finance & $\begin{array}{l}-0.025 \\
(0.148)\end{array}$ & $\begin{array}{l}-0.025 \\
(0.143)\end{array}$ & $\begin{array}{l}-0.003 \\
(0.011)\end{array}$ & $\begin{array}{l}-0.003 \\
(0.011)\end{array}$ & $\begin{array}{c}0.004 \\
(0.004)\end{array}$ & $\begin{array}{c}0.004 \\
(0.004)\end{array}$ \\
\hline Unemployment rate & $\begin{array}{l}-0.035 \\
(0.099)\end{array}$ & $\begin{array}{l}-0.038 \\
(0.099)\end{array}$ & $\begin{array}{c}-0.012 \\
(0.100)\end{array}$ & $\begin{array}{c}-0.016 \\
(0.101)\end{array}$ & $\begin{array}{c}0.130 \\
(0.115)\end{array}$ & $\begin{array}{c}0.126 \\
(0.115)\end{array}$ \\
\hline School years & $\begin{array}{c}1.679^{\star * *} \\
(0.545)\end{array}$ & $\begin{array}{l}1.603^{\star *} \\
(0.655)\end{array}$ & $\begin{array}{c}1.736^{\star * *} \\
(0.611)\end{array}$ & $\begin{array}{l}1.676^{* *} \\
(0.721)\end{array}$ & $\begin{array}{c}0.425 \\
(0.756)\end{array}$ & $\begin{array}{c}0.228 \\
(0.846)\end{array}$ \\
\hline Trade openness & $\begin{array}{c}0.002 \\
(0.018)\end{array}$ & $\begin{array}{c}0.001 \\
(0.019)\end{array}$ & $\begin{array}{c}0.002 \\
(0.019)\end{array}$ & $\begin{array}{c}0.001 \\
(0.021)\end{array}$ & $\begin{array}{c}0.010 \\
(0.016)\end{array}$ & $\begin{array}{c}0.005 \\
(0.018)\end{array}$ \\
\hline Labour share & - & $\begin{array}{c}-0.017 \\
(0.080)\end{array}$ & - & $\begin{array}{l}-0.015 \\
(0.072)\end{array}$ & - & $\begin{array}{l}-0.044 \\
(0.061)\end{array}$ \\
\hline Year fixed effects & Yes & Yes & Yes & Yes & Yes & Yes \\
\hline Linear country trends & Yes & Yes & Yes & Yes & Yes & Yes \\
\hline R-squared & 0.979 & 0.979 & 0.980 & 0.980 & 0.982 & 0.982 \\
\hline Sample period & $1974-2010$ & $1974-2010$ & $1974-2010$ & $1974-2010$ & $1989-2010$ & $1989-2010$ \\
\hline Observations & 240 & 240 & 240 & 240 & 204 & 204 \\
\hline
\end{tabular}

Note: All regressions are OLS and contain country fixed effects. Standard errors, which are shown in brackets, are clustered at the country-level. ${ }^{* * *}$ indicates significance at the $1 \%$ level, ${ }^{* *}$ at the $5 \%$ level and * at the $10 \%$ level. The Gini coefficient is expressed in Gini points and based on household disposable income adjusted for household size. Value added of finance is financial and insurance activities divided by GDP, intermediated credit is credit to the non-financial private sector by financial institutions divided by GDP, and stock market capitalisation is the value of all shares listed in a stock market divided by GDP. School years is average years of schooling in the population aged 25 and over, trade openness is the sum of exports and imports divided by GDP, and labour share is labour compensation divided by GDP. The sample covers OECD countries.

Source: OECD Secretariat calculations using OECD Structural Analysis database; World Bank Global Financial Development database; Bank for International Settlements credit series; Statistics Canada; OECD Income Distribution and Poverty database; OECD Economic Outlook database; R. J. Barro and J. W. Lee (2013), "A New Data Set of Educational Attainment in the World, 1950-2010", Journal of Development Economics, 104, pp. 184-198; EU-KLEMS database; WORLD-KLEMS database. 


\section{Examining causality in the negative relationship between credit and income equality}

25. The positive relationship between the different measures of finance and the Gini coefficient does not imply with certainty that less finance would reduce income inequality. For example, causality may run in the other direction, i.e. higher inequality might raise the amount of finance in the economy. This would, for instance, be the case if credit is used by low-income households to reduce consumption inequality when income inequality is high (Kumhof et al., 2015; Rajan, 2010). Using new evidence from the euro area, this section sheds light on the plausibility of such endogeneity concerns in the estimated relationships. It argues that at least some degree of causality is likely to run from more finance to higher inequality.

26. Cournède and Denk (2015) use financial deregulation indicators as instrumental variables for the size of finance to examine causality in the link from finance to GDP growth. However, the same approach cannot be implemented to study the link between finance and inequality due to the much smaller number of observations for the Gini coefficient. Nevertheless, in the absence of suitable instruments for the overall link between finance and inequality, testing the implications of particular channels can provide insights about the nature of the relationship. The focus is on intermediated credit, since greater income inequality seems unlikely to boost stock market capitalisation.

27. Two complementary approaches are followed to investigate the conjecture that growing income inequality induces higher levels of credit:

- The distribution of credit and income inequality: the Keeping-up-with-the-Joneses motive suggests that low- and middle-income households should hold relatively more credit in countries with high income inequality.

- Bank credit to households versus other types of credit: if households took on more debt to limit the difference in their consumption with people at the top of the distribution, the positive link between credit and inequality should be particularly tight for bank credit to households.

\subsection{The distribution of credit and income inequality}

28. A direct test of reverse causality from inequality to credit is to correlate the shares of household credit that go to households at different points in the income distribution with income inequality across countries. According to recent US evidence, low earners in high-inequality regions accumulated less debt during 2001-11 than their counterparts in low-inequality regions (Coibion et al., 2014). Causality, at least during the global financial crisis in the United States, has therefore likely run from more credit to higher inequality, although there is also some conflicting evidence (Bertrand and Morse, 2014). Similarly, crosscountry data indicate that banking crises have not often been preceded by rising inequality (Atkinson and Morelli, 2011; Bordo and Meissner, 2012), even if also this finding has been disputed (Gu and Huang, 2014). Ramskogler (2015) surveys the existing literature more extensively.

29. This report takes a somewhat different angle to study this issue empirically for a sample of euro area countries. The new Eurosystem Household Finance and Consumption Survey (for further details, see Denk and Cazenave-Lacroutz, 2015) enables to calculate the share of total household credit that was held by each quintile in the income distribution in 2010. If inequality spurs credit demand by, or credit supply to, households towards the bottom of the distribution, these households should hold relatively more credit in countries with high inequality.

30. Evidence from the euro area shows that households in the lower half of the income distribution do not hold a larger share of economy-wide credit in more inegalitarian countries (Figure 4). The slope coefficients are far from statistical significance for all quintiles, and they are not statistically different from 
each other. In Portugal and Italy, two of the more unequal countries in the euro area, relatively more credit actually goes to the top $20 \%$, which contributes to the positive slope of the line for households in this part of the distribution. Further support is provided by complementary analysis according to which the creditto-income, or leverage, ratio of households in the two bottom quintiles is not greater in high-inequality countries, relative to their counterparts in low-inequality countries and to the top quintile in high-inequality countries (Figure 5). As a whole, these results are inconsistent with the concern that causality runs from income inequality to credit provision, while they should also not be viewed as establishing beyond doubt that causality runs from credit provision to income inequality.

Figure 4. Distribution of household credit across income groups and income inequality

Euro area countries, 2010

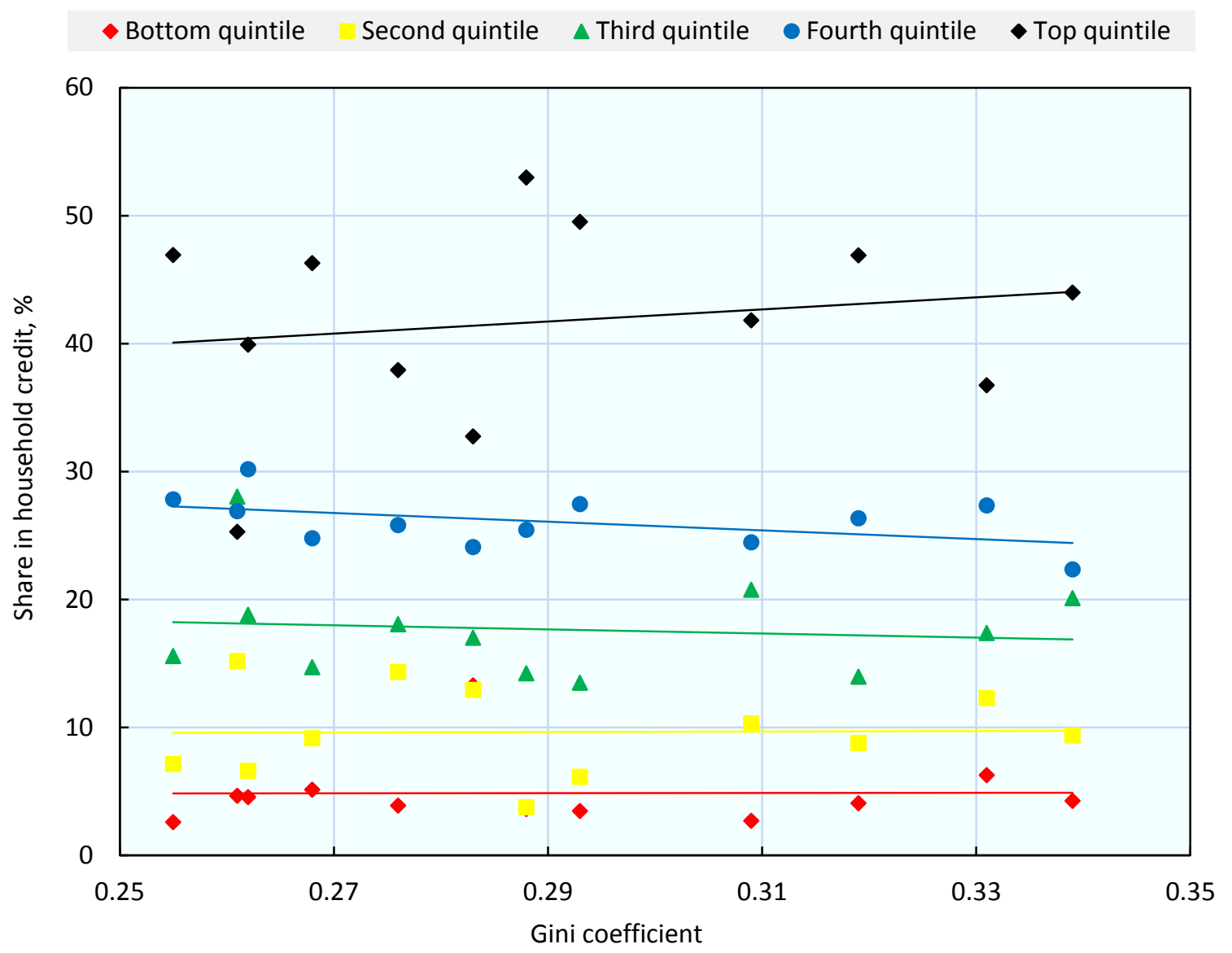

Note: The data cover 12 euro area countries. The Gini coefficient is based on household disposable income adjusted for household size. Income quintiles are based on annual household gross income. The lines indicate the fitted values from OLS regressions of a quintile's share in household credit on the Gini coefficient.

Source: OECD Secretariat calculations using OECD Income Distribution and Poverty database; Eurosystem Household Finance and Consumption Survey. 
ECO/WKP(2015)42

Figure 5. Credit-to-income ratio across income groups and income inequality

Euro area countries, 2010

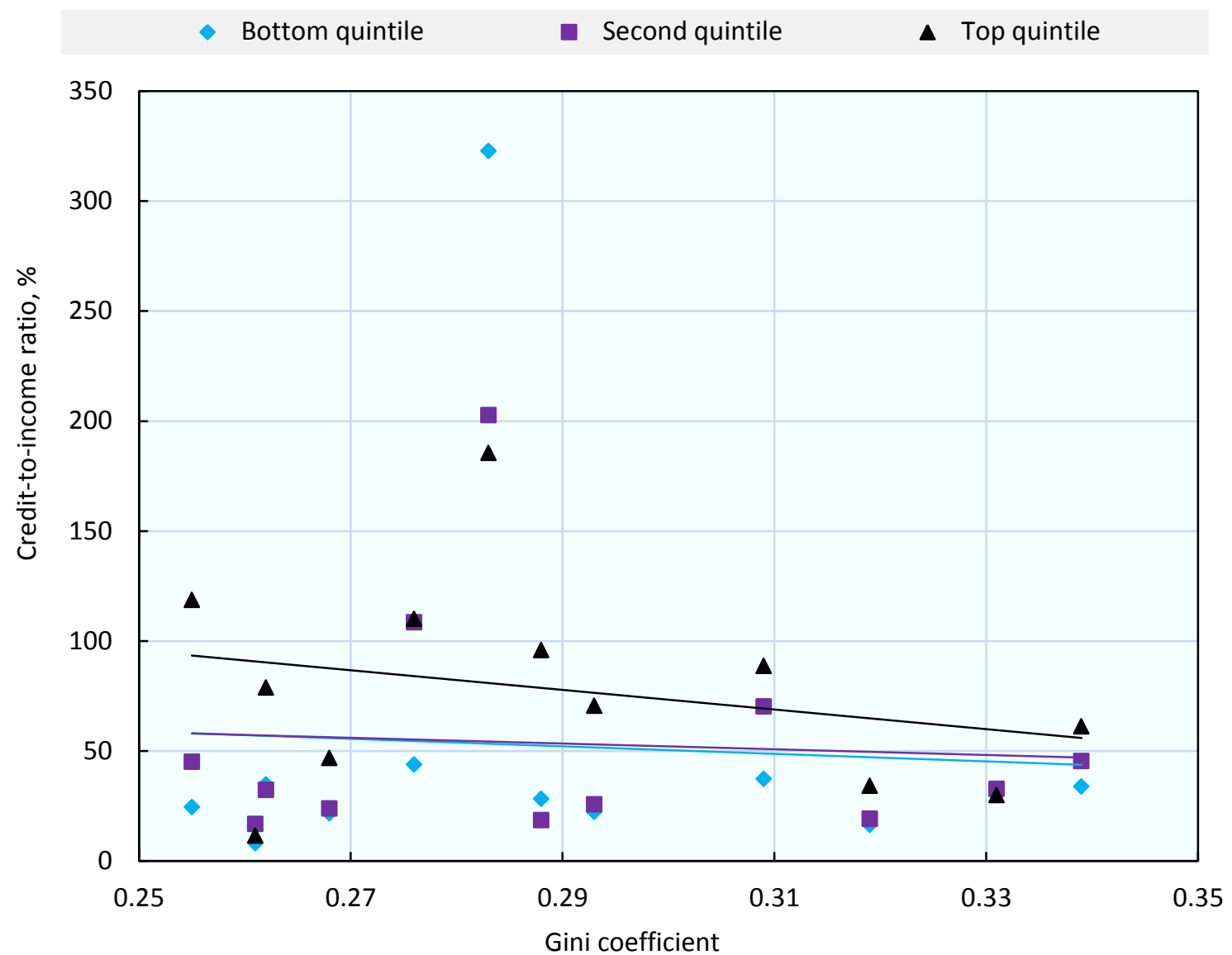

Note: The data cover 12 euro area countries. The Gini coefficient is based on household disposable income adjusted for household size. Credit-to-income ratio is total household credit of an income quintile divided by total household disposable income of the income quintile. Income quintiles are based on annual household gross income for credit and on disposable income for income. Total household disposable income of a quintile is calculated by multiplying household disposable income in the national accounts with the quintile's proportion of total disposable income in the OECD Income Distribution and Poverty database. The lines indicate the fitted values from OLS regressions of a quintile's credit-to-income ratio on the Gini coefficient. The data for the third and fourth quintiles are not shown, as they overlap closely with the ones in the chart.

Source: OECD Secretariat calculations using OECD Income Distribution and Poverty database; OECD Economic Outlook database; Eurosystem Household Finance and Consumption Survey.

\subsection{Bank credit to households versus other types of credit}

31. Credit series for the past three decades allow analysing the relationship between income equality and different forms of credit. The data separate total credit (loans, bonds and short-term paper) along two dimensions: $i$ ) by type of borrower (credit to households versus credit to non-financial corporations), and ii) by type of lender (bank credit versus non-bank credit). ${ }^{6}$ However, bank credit to households is not

6. For credit to households and credit to non-financial corporations, lenders are deposit money banks, other financial institutions, non-financial corporations, central banks, general government, households and nonprofit institutions serving households. Deposit money banks are the sole lender for bank credit, and lenders for non-bank credit are the same as for credit to households and credit to non-financial corporations, except deposit money banks. 
available. Credit to households and bank credit are both individually tested for a particularly tight link with the Gini coefficient. ${ }^{7}$

32. The data contradict the prediction that growing income inequality induces higher levels of bank credit to households. Credit to households and bank credit exhibit a less positive association with the Gini coefficient than, respectively, credit to corporations and non-bank credit. When credit to households and credit to corporations are simultaneously included as explanatory variables in the baseline specification (Equation 1), credit to households attracts a smaller coefficient than credit to corporations. Similarly, when bank credit and non-bank credit are jointly included as explanatory variables, the point estimate is lower for bank credit than non-bank credit. Therefore, bank credit to households is not larger than other types of private sector borrowing when income inequality is high. The absence of such a link is not in line with the hypothesis that high income inequality led to more credit provision to households at the lower end of the income distribution in euro area countries.

\section{Finance and household income growth across the income distribution}

33. The empirical analyses in Section 2 documented a negative relationship of intermediated credit and stock market capitalisation with income equality. Yet, higher inequality associated with financial expansion will be a less important problem for individual welfare and social cohesion if it does not at the same time negatively affect household income growth, especially of low earners. This consideration calls for an examination of the relationship of finance with disposable income growth at different points in the income distribution. Cournède and Denk (2015) show that higher intermediated credit is linked with slower GDP growth. Insofar as output and disposable income growth are related, this suggests that credit expansion has a negative influence on low-income households through two channels: slower income growth and more dispersed incomes. By contrast, the positive link of stock market capitalisation with GDP growth, also established in Cournède and Denk (2015), points to a trade-off between stronger income growth and higher income inequality. The cumulative effect on the income growth for low-income households is then an empirical question in the case of stock markets.

34. The section begins with a review of the econometric estimates in Cournède and Denk (2015) for the links of financial size with GDP growth. It then investigates the correlation of finance with aggregate household disposable income growth. The final part simulates the association of intermediated credit and stock market capitalisation with the income growth of households at different points in the distribution.

35. This empirical approach goes beyond the narrow focus of the finance-inequality nexus, outlining a novel methodology that combines different estimates to account for both income growth and income inequality concerns for policy analysis. The framework is intuitive and does not involve complex computations. It is not confined to the context of finance and could be used to study the influence of other public policies on the income growth of households across the distribution. The method complements previous OECD work (Causa et al., 2014) analysing the relationship between GDP and household income growth.

\subsection{The links between finance and GDP growth in OECD countries}

36. Cournède and Denk (2015) investigate the relationship between finance and GDP growth across OECD countries. At the levels observed over past decades, a higher value added of finance and more intermediated credit, relative to their country-specific average and trend, are tightly associated with weaker

7. The share of credit to households in total credit varies from $15 \%$ in Luxembourg to $61 \%$ in Australia across OECD countries. The share of bank credit in total credit has an even wider dispersion, ranging from $23 \%$ in Belgium to $89 \%$ in Greece. These data are for 2011. 
economic growth (controlling for relevant additional explanatory variables). Relative to trend, an increase in intermediated credit by $10 \%$ of a country's GDP is linked with 0.3 percentage points slower GDP growth. Moreover, since more intermediated credit is associated with a more unequal income distribution (Section 2), its overall relationship with household income growth is likely to be more negative for individuals at the bottom of the distribution than at the top. A greater value added share of finance in GDP is also associated with slower GDP growth. By contrast, more stock market capitalisation has a statistically significant positive link with GDP growth.

37. Typical wage shares of around two-thirds of GDP suggest that household income growth tends to co-move with GDP growth. Nonetheless, it is possible that the declining wage shares over the past halfcentury in many OECD countries influence the size and sign of the relationship between finance and household income growth. Plotting per capita growth of real household disposable income in OECD countries against the three measures of finance reveals that the relationship is insignificant for the value added of finance, negative for intermediated credit and positive for stock market capitalisation (Figures 6-8). All observations are demeaned to eliminate persistent cross-country differences. As with per capita GDP growth, however, one concern with these simple correlations is that they may be due to common time trends in finance and household income growth. The next subsection therefore turns to regressions which control for possibly confounding trends and other explanatory variables.

Figure 6. The bivariate relationship between the value added of finance and household income growth

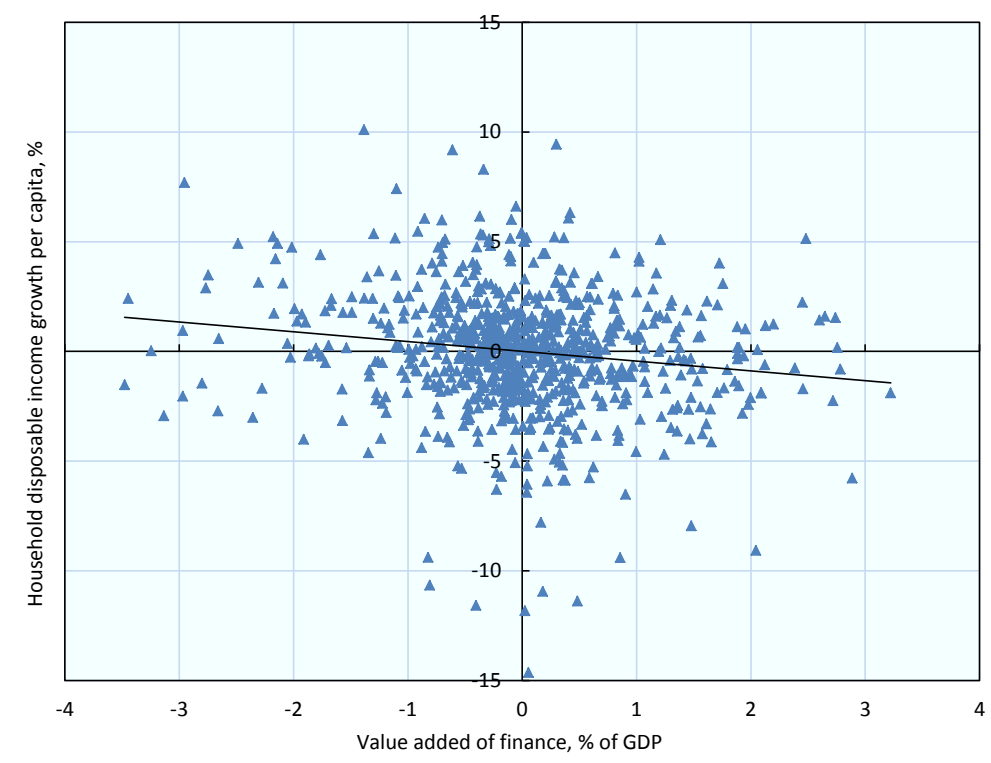

Note: The data cover 31 OECD countries between 1970 and 2011. Value added of finance is financial and insurance activities. The line indicates the fitted values from an OLS regression through the data points. The two variables are demeaned using each country's mean to average out differences between countries that are persistent over time.

Source: OECD Structural Analysis database; OECD Economic Outlook database; OECD Secretariat calculations. 


\section{ECO/WKP(2015)42}

Figure 7. The bivariate relationship between intermediated credit and household income growth

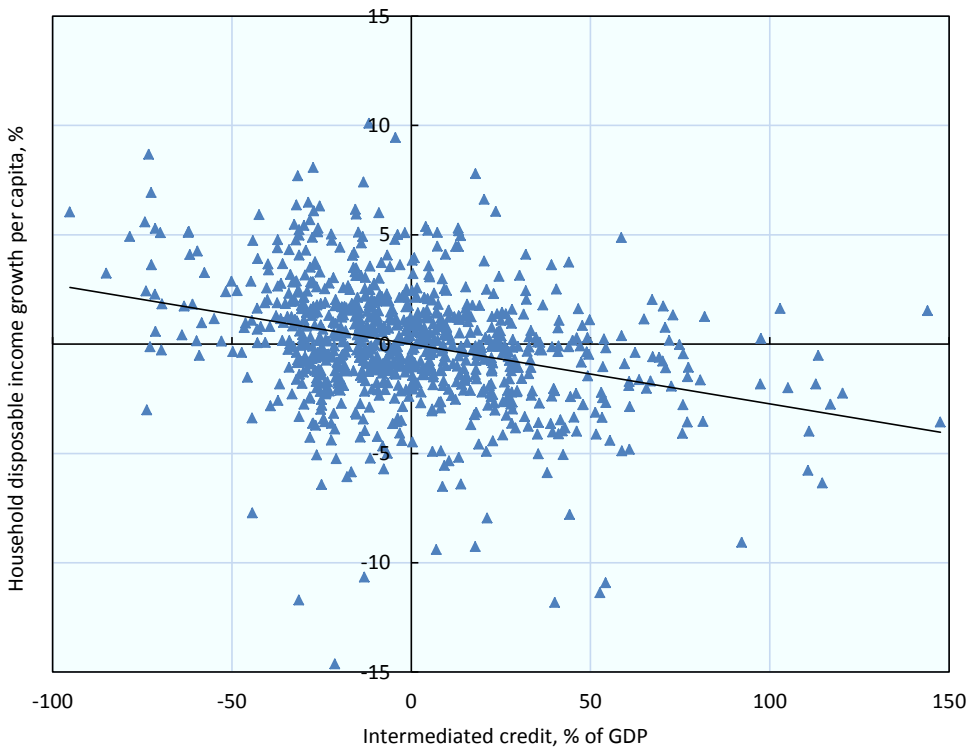

Note: The data cover 30 OECD countries between 1961 and 2011. Intermediated credit is credit to the non-financial private sector by financial institutions. The line indicates the fitted values from an OLS regression through the data points. The two variables are demeaned using each country's mean to average out differences between countries that are persistent over time.

Source: World Bank Global Financial Development database; Bank for International Settlements credit series; Statistics Canada; OECD Economic Outlook database; OECD Secretariat calculations.

Figure 8. The bivariate relationship between stock market capitalisation and household income growth

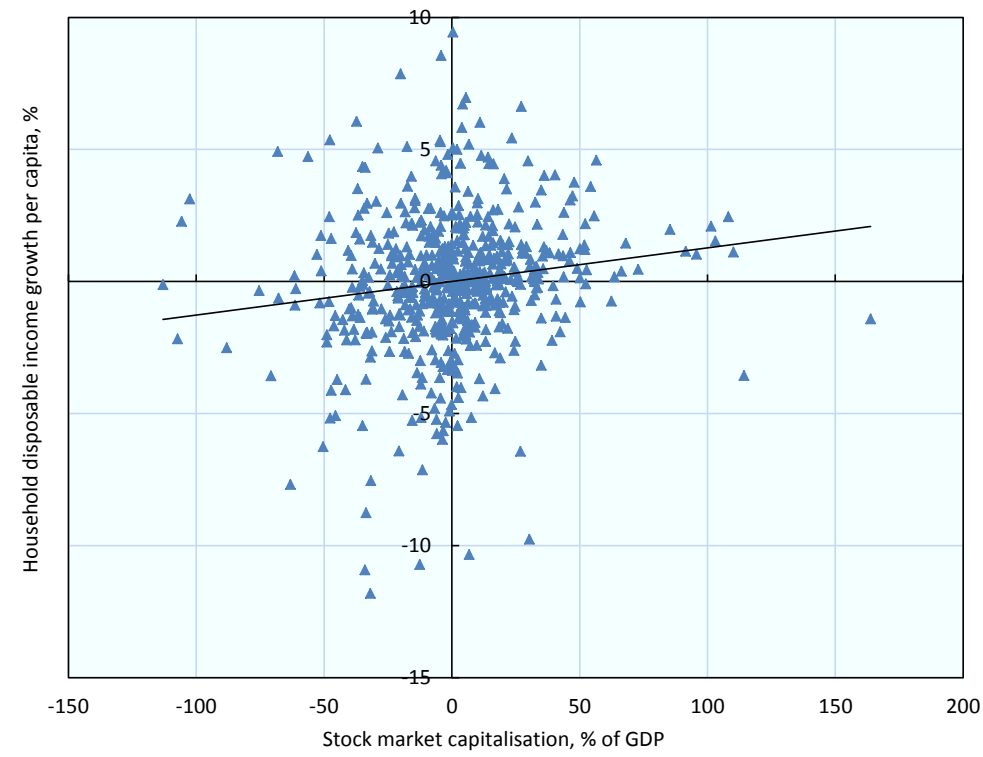

Note: The data cover 30 OECD countries between 1989 and 2011. Stock market capitalisation is the value of all shares listed in a stock market. The line indicates the fitted values from an OLS regression through the data points. The two variables are demeaned using each country's mean to average out differences between countries that are persistent over time.

Source: World Bank Global Financial Development database; OECD Economic Outlook database; OECD Secretariat calculations. 


\subsection{The links between finance and household income growth in OECD countries}

38. To estimate the links between finance and household income growth, the same regression set-up is used as in Cournède and Denk (2015). The sole modification is that per capita growth of real household disposable income, IncGrowth It $_{\text {, }}$ replaces per capita growth of real GDP:

$$
\text { IncGrowth }_{c t}=\beta \text { Fin }_{c t}+x_{c t} \gamma+\rho_{c}+\tau_{t}+\varphi_{c} t+\varepsilon_{c t} .
$$

Measures of finance, $\mathrm{Fin}_{c t}$, are again the value added of finance, intermediated credit and stock market capitalisation. The control variables are gross fixed capital formation (or the investment rate), the stock of human capital proxied by average years of schooling of the adult population and the growth rate of the working age population. As with the regression for income inequality (Equation 1), the coefficient on finance is to be interpreted as capturing the link between changes in the size of finance and changes in income growth in one country relative to others. Furthermore, although the exogenous covariates, country and year fixed effects and country-specific linear time trends remove several sources of endogeneity, implications about causality should not be drawn beyond this.

39. No statistically significant relationship is established for the value added of finance with income growth in any of the specifications (Table 5): with country fixed effects (Column 1), when the standard control variables are added (Column 2) as well as year fixed effects (Column 3), when country-specific linear time trends are introduced (Column 4), observations from 2007 and later excluded (Column 5), and when an indicator variable for years with a financial crisis is included (Column 6). The absence of a link of the value added of finance with both income growth and income inequality suggests that changes in the value added of finance are not related with the absolute and relative levels of household incomes across the distribution.

40. In stark contrast, household income growth has a tight statistically significant negative link with intermediated credit across all specifications (Table 6). The set of regressions is the same as for the value added of finance. The coefficient in the baseline specification of Column $4(-0.031)$ is very close to the one with GDP growth (-0.029) in Cournède and Denk (2015). A reduction in intermediated credit by $10 \%$ of GDP is associated with a rise of disposable income growth by 0.3 percentage points. As with GDP growth, stock market expansions have a strong statistically significant association with higher household income growth (Table 7). This result holds across all regressions, and the coefficient in the baseline specification of Column 4 (0.022) is again close to the one with GDP growth (0.018) in Cournède and Denk (2015). 
Table 5. The relationship between the value added of finance and household income growth per capita

\begin{tabular}{|c|c|c|c|c|c|c|}
\hline \multirow[t]{2}{*}{ Dependent variable: } & \multicolumn{6}{|c|}{ Household disposable income growth per capita } \\
\hline & (1) & (2) & $(3)$ & (4) & $(5)$ & (6) \\
\hline Value added of finance & $\begin{array}{l}-0.445 \\
(0.263)\end{array}$ & $\begin{array}{c}-0.308 \\
(0.249)\end{array}$ & $\begin{array}{l}-0.430 \\
(0.276)\end{array}$ & $\begin{array}{l}-0.388 \\
(0.361)\end{array}$ & $\begin{array}{l}-0.474 \\
(0.487)\end{array}$ & $\begin{array}{l}-0.340 \\
(0.338)\end{array}$ \\
\hline Investment rate & - & $\begin{array}{c}0.288^{\star \star \star *} \\
(0.086)\end{array}$ & $\begin{array}{c}0.245^{\star \star \star *} \\
(0.071)\end{array}$ & $\begin{array}{c}0.312^{* \star *} \\
(0.085)\end{array}$ & $\begin{array}{c}0.247^{\star \star \star *} \\
(0.087)\end{array}$ & $\begin{array}{c}0.288^{\star * \star} \\
(0.092)\end{array}$ \\
\hline School years & - & $\begin{array}{l}-0.258 \\
(0.196)\end{array}$ & $\begin{array}{c}-0.898^{\star *} \\
(0.423)\end{array}$ & $\begin{array}{c}0.378 \\
(0.845)\end{array}$ & $\begin{array}{c}0.498 \\
(1.243)\end{array}$ & $\begin{array}{c}0.411 \\
(0.728)\end{array}$ \\
\hline Population growth & - & $\begin{array}{l}-0.121 \\
(0.462)\end{array}$ & $\begin{array}{c}0.026 \\
(0.375)\end{array}$ & $\begin{array}{c}-0.524^{* *} \\
(0.253)\end{array}$ & $\begin{array}{c}-0.743^{\star * *} \\
(0.265)\end{array}$ & $\begin{array}{c}-0.487^{* *} \\
(0.225)\end{array}$ \\
\hline Banking crisis dummy & - & - & - & - & - & $\begin{array}{c}-1.365^{\star *} \\
(0.590)\end{array}$ \\
\hline Year fixed effects & No & No & Yes & Yes & Yes & Yes \\
\hline Linear country trends & No & No & No & Yes & Yes & Yes \\
\hline R-squared & 0.157 & 0.241 & 0.360 & 0.447 & 0.440 & 0.458 \\
\hline Sample period & $1970-2011$ & $1970-2011$ & $1970-2011$ & $1970-2011$ & $1970-2006$ & $1970-2011$ \\
\hline Observations & 793 & 793 & 793 & 793 & 653 & 793 \\
\hline
\end{tabular}

Note: All regressions are OLS and include country fixed effects. Standard errors, which are shown in brackets, are clustered at the country-level. *** indicates significance at the $1 \%$ level, ** at the $5 \%$ level and * at the 10\% level. Value added of finance is financial and insurance activities divided by GDP, investment rate is gross fixed capital formation divided by GDP, school years is average years of schooling in the population aged 25 and over, and population growth is the growth rate of the population aged $15-64$. The sample covers 31 OECD countries (30 in Column 5).

Source: OECD Secretariat calculations using OECD Structural Analysis database; OECD Economic Outlook database; R. J. Barro and J. W. Lee (2013), "A New Data Set of Educational Attainment in the World, 1950-2010", Journal of Development Economics, 104, pp. 184-198; World Bank World Development Indicators database; L. Laeven and F. Valencia (2013), "Systemic Banking Crises Database", IMF Economic Review, 61(2), pp. 225-270. 
Table 6. The relationship between intermediated credit and household income growth per capita

\begin{tabular}{|c|c|c|c|c|c|c|}
\hline \multirow[t]{2}{*}{ Dependent variable: } & \multicolumn{6}{|c|}{ Household disposable income growth per capita } \\
\hline & $(1)$ & $(2)$ & $(3)$ & (4) & $(5)$ & (6) \\
\hline Intermediated credit & $\begin{array}{c}-0.027^{\star \star *} \\
(0.006)\end{array}$ & $\begin{array}{c}-0.021^{* * *} \\
(0.006)\end{array}$ & $\begin{array}{c}-0.032^{* * *} \\
(0.006)\end{array}$ & $\begin{array}{c}-0.031^{* * *} \\
(0.007)\end{array}$ & $\begin{array}{c}-0.030^{* *} \\
(0.011)\end{array}$ & $\begin{array}{l}-0.022^{\star *} \\
(0.009)\end{array}$ \\
\hline Investment rate & - & $\begin{array}{c}0.287^{\star * *} \\
(0.081)\end{array}$ & $\begin{array}{c}0.295^{\star \star *} \\
(0.083)\end{array}$ & $\begin{array}{c}0.319^{\star \star \star} \\
(0.086)\end{array}$ & $\begin{array}{c}0.256^{\star \star *} \\
(0.088)\end{array}$ & $\begin{array}{c}0.310^{\star \star * *} \\
(0.097)\end{array}$ \\
\hline School years & - & $\begin{array}{l}-0.007 \\
(0.216)\end{array}$ & $\begin{array}{c}-0.854^{* * *} \\
(0.311)\end{array}$ & $\begin{array}{c}0.279 \\
(0.603)\end{array}$ & $\begin{array}{c}0.381 \\
(0.658)\end{array}$ & $\begin{array}{c}0.015 \\
(0.691)\end{array}$ \\
\hline Population growth & - & $\begin{array}{c}0.010 \\
(0.449)\end{array}$ & $\begin{array}{c}0.123 \\
(0.418)\end{array}$ & $\begin{array}{l}-0.373 \\
(0.253)\end{array}$ & $\begin{array}{c}-0.347^{\star *} \\
(0.166)\end{array}$ & $\begin{array}{l}-0.449^{*} \\
(0.265)\end{array}$ \\
\hline Banking crisis dummy & - & - & - & - & - & $\begin{array}{c}-1.123 \\
(0.666)\end{array}$ \\
\hline Year fixed effects & No & No & Yes & Yes & Yes & Yes \\
\hline Linear country trends & No & No & No & Yes & Yes & Yes \\
\hline R-squared & 0.213 & 0.283 & 0.399 & 0.467 & 0.458 & 0.448 \\
\hline Sample period & $1961-2011$ & $1961-2011$ & $1961-2011$ & $1961-2011$ & $1961-2006$ & $1961-2011$ \\
\hline Observations & 881 & 881 & 881 & 881 & 753 & 831 \\
\hline
\end{tabular}

Note: All regressions are OLS and include country fixed effects. Standard errors, which are shown in brackets, are clustered at the country-level. *** indicates significance at the $1 \%$ level, ${ }^{* *}$ at the $5 \%$ level and * at the $10 \%$ level. Intermediated credit is credit to the non-financial private sector by financial institutions divided by GDP, investment rate is gross fixed capital formation divided by GDP, school years is average years of schooling in the population aged 25 and over, and population growth is the growth rate of the population aged 15-64. The sample covers 30 OECD countries (29 in Column 5).

Source: OECD Secretariat calculations using World Bank Global Financial Development database; Bank for International Settlements credit series; Statistics Canada; OECD Economic Outlook database; R. J. Barro and J. W. Lee (2013), "A New Data Set of Educational Attainment in the World, 1950-2010", Journal of Development Economics, 104, pp. 184-198; World Bank World Development Indicators database; L. Laeven and F. Valencia (2013), "Systemic Banking Crises Database", IMF Economic Review, 61(2), pp. 225-270. 
Table 7. The relationship between stock market capitalisation and household income growth per capita

\begin{tabular}{|c|c|c|c|c|c|c|}
\hline \multirow[t]{2}{*}{ Dependent variable: } & \multicolumn{6}{|c|}{ Household disposable income growth per capita } \\
\hline & $(1)$ & (2) & (3) & (4) & (5) & (6) \\
\hline Stock market capitalisation & $\begin{array}{l}0.013^{* *} \\
(0.005)\end{array}$ & $\begin{array}{c}0.017^{* \star *} \\
(0.005)\end{array}$ & $\begin{array}{l}0.015^{\star *} \\
(0.007)\end{array}$ & $\begin{array}{c}0.022^{* * \star} \\
(0.008)\end{array}$ & $\begin{array}{l}0.024^{*} \\
(0.012)\end{array}$ & $\begin{array}{c}0.019^{\star * \star} \\
(0.006)\end{array}$ \\
\hline Investment rate & - & $\begin{array}{c}0.425^{\star * *} \\
(0.059)\end{array}$ & $\begin{array}{c}0.386^{* * *} \\
(0.063)\end{array}$ & $\begin{array}{c}0.481^{* * *} \\
(0.076)\end{array}$ & $\begin{array}{c}0.384^{* * *} \\
(0.074)\end{array}$ & $\begin{array}{c}0.467^{\star * *} \\
(0.083)\end{array}$ \\
\hline School years & - & $\begin{array}{c}-0.669^{* *} \\
(0.310)\end{array}$ & $\begin{array}{l}-0.393 \\
(0.511)\end{array}$ & $\begin{array}{c}1.572 \\
(1.032)\end{array}$ & $\begin{array}{c}1.200 \\
(1.636)\end{array}$ & $\begin{array}{c}1.485 \\
(1.032)\end{array}$ \\
\hline Population growth & - & $\begin{array}{c}-0.694^{* *} \\
(0.302)\end{array}$ & $\begin{array}{c}-0.756^{* * *} \\
(0.276)\end{array}$ & $\begin{array}{l}-0.639 \\
(0.397)\end{array}$ & $\begin{array}{l}-0.407 \\
(0.330)\end{array}$ & $\begin{array}{l}-0.650 \\
(0.404)\end{array}$ \\
\hline Banking crisis dummy & - & - & - & - & - & $\begin{array}{l}-0.701 \\
(0.606)\end{array}$ \\
\hline Year fixed effects & No & No & Yes & Yes & Yes & Yes \\
\hline Linear country trends & No & No & No & Yes & Yes & Yes \\
\hline R-squared & 0.147 & 0.317 & 0.370 & 0.465 & 0.455 & 0.468 \\
\hline Sample period & $1989-2011$ & $1989-2011$ & $1989-2011$ & $1989-2011$ & 1989-2006 & $1989-2011$ \\
\hline Observations & 592 & 592 & 592 & 592 & 447 & 592 \\
\hline
\end{tabular}

Note: All regressions are OLS and include country fixed effects. Standard errors, which are shown in brackets, are clustered at the country-level. ${ }^{* *}$ indicates significance at the $1 \%$ level, ${ }^{* *}$ at the $5 \%$ level and ${ }^{*}$ at the $10 \%$ level. Stock market capitalisation is the value of all shares listed in a stock market divided by GDP, investment rate is gross fixed capital formation divided by GDP, school years is average years of schooling in the population aged 25 and over, and population growth is the growth rate of the population aged 15-64. The sample covers 30 OECD countries (29 in Column 5).

Source: OECD Secretariat calculations using World Bank Global Financial Development database; OECD Economic Outlook database; R. J. Barro and J. W. Lee (2013), "A New Data Set of Educational Attainment in the World, 1950-2010", Journal of Development Economics, 104, pp. 184-198; World Bank World Development Indicators database; L. Laeven and F. Valencia (2013), "Systemic Banking Crises Database", IMF Economic Review, 61(2), pp. 225-270. 


\subsection{Quantifying the overall association between finance and household income growth}

41. The previous subsection and Section 2 yield estimates for the association of intermediated credit and stock market capitalisation with $i$ ) per capita growth of total household disposable income and ii) the distribution of household disposable income. Hence, these two measures of finance can now be related with household disposable income growth at different points in the income distribution. In essence, the link between more finance with income growth for a particular income decile can be simulated as the combination of two components: one from the income growth regression and the other from the income inequality regression. Box 1 describes the technical details.

\section{Box 1. The approach to estimate the relationship between finance and income growth across the distribution}

This box outlines the approach employed to simulate the association of intermediated credit and stock market capitalisation with the disposable income growth of a particular decile in the income distribution. Income of decile $d=\{1, \ldots, 10\}$ can be written as: $I^{d}=s^{d} I$, where $s^{d}$ is the decile's share in total income $I$. The percentage change in the income of decile $d$ associated with a small to moderate change in the size of finance $\Delta F$ is then:

$$
\frac{\Delta I^{d} / \Delta F}{I^{d}}=\frac{\Delta s^{d} / \Delta F}{s^{d}}+\frac{\Delta I / \Delta F}{I} .
$$

The second additive term is the percentage change in aggregate income that is related with the change in the size of finance. It is estimated by the baseline regressions in Column 4 of Tables 6-7. In the simulation, the change in finance is set at $\Delta F=10 \%$ of GDP. The first additive term is the percentage change in the decile's income share. Its calculation proceeds in three steps:

- In the first step, ten OLS regressions of the income share of each decile on the Gini coefficient are run. The resulting coefficients indicate the change in a decile's income share associated with a one-point change in the Gini.

- In the second step, the slope coefficients from the OLS regressions above are multiplied by the change in the Gini coefficient related with an increase in intermediated credit or stock market capitalisation by $10 \%$ of GDP. The calculations use as inputs the estimates from the baseline specification in Column 4 of Tables 2-3.

- In the final step, the predicted change in the income share of each decile, when finance expands by $10 \%$ of GDP, is divided by the average income share of the decile. This yields the percentage change in disposable income resulting from the estimated link of finance with inequality.

The inequality regressions are based on the level of income, while the growth regressions are based on income growth. However, for the relatively small positive income growth rates experienced in OECD countries the percentage changes in the level of income are a close approximation of the percentage point changes in the income growth rate, and vice versa.

42. One missing link remains to be addressed: the one between the Gini coefficient and changes in the disposable income of households. The income shares of the seven bottom deciles decline with the Gini coefficient, while those of the two top deciles increase with the Gini coefficient, in a remarkably linear fashion across years and OECD countries (Figure 9). Ten OLS regressions of the income share of each decile on the Gini coefficient estimate the average links between the Gini coefficient and income shares. 
Figure 9. Income shares of different income deciles and income inequality

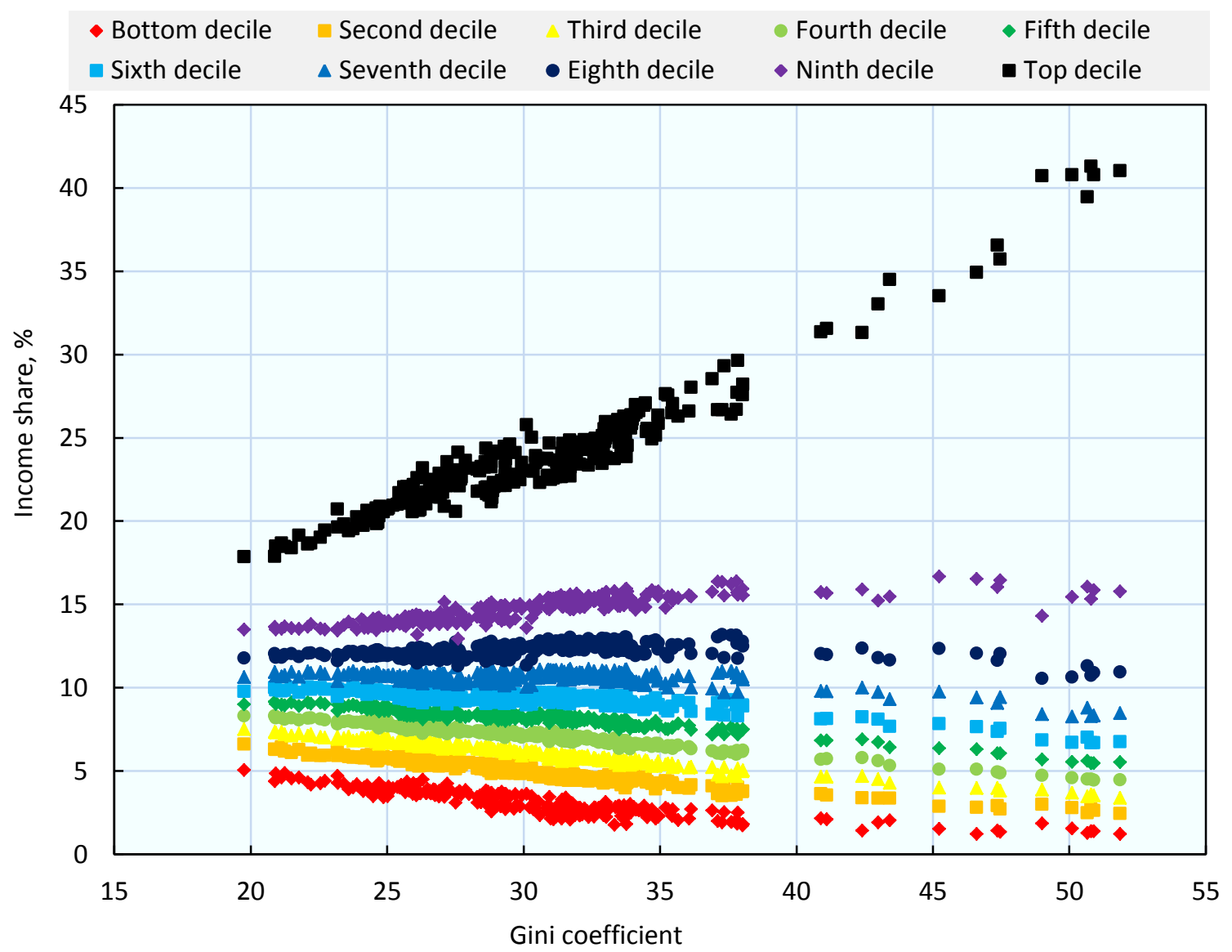

Note: Deciles and the Gini coefficient are based on household disposable income adjusted for household size. The income share of a decile refers to its disposable income divided by aggregate disposable income in the economy.

Source: OECD Secretariat calculations using OECD Income Distribution and Poverty database.

43. These three ingredients, that is to say the estimated relationships of (1) finance with aggregate income growth, (2) finance with the Gini coefficient and (3) the Gini coefficient with relative income levels by decile, provide a basis for two experiments. The first one simulates the impact of a $10 \%$ of GDP increase in intermediated credit on income growth by decile. The second one does the same for an increase in stock market capitalisation, also by $10 \%$ of GDP.

44. Higher intermediated credit is linked with a slowdown of disposable income growth for all except the top $10 \%$ earners (Figure 10). A credit rise by $10 \%$ of GDP implies that income growth slows for the bottom $10 \%$ by 0.8 and for the two middle deciles by $0.4-0.5$ percentage points, while it increases for the top decile by 0.1 percentage points. The monotonic rise of the estimate from the bottom to the top of the income distribution results from the positive link between intermediated credit and the Gini coefficient, together with the relationships between income shares and the Gini coefficient. The horizontal line indicates the slowdown of aggregate household income growth. The change in income growth averaged across the ten deciles is more negative than the change in income growth for the whole economy, due to the skewed distribution of income and the positive association between intermediated credit and income inequality. 
ECO/WKP(2015)42

Figure 10. Changes in household income growth for different income deciles from an expansion of intermediated credit by $10 \%$ of GDP

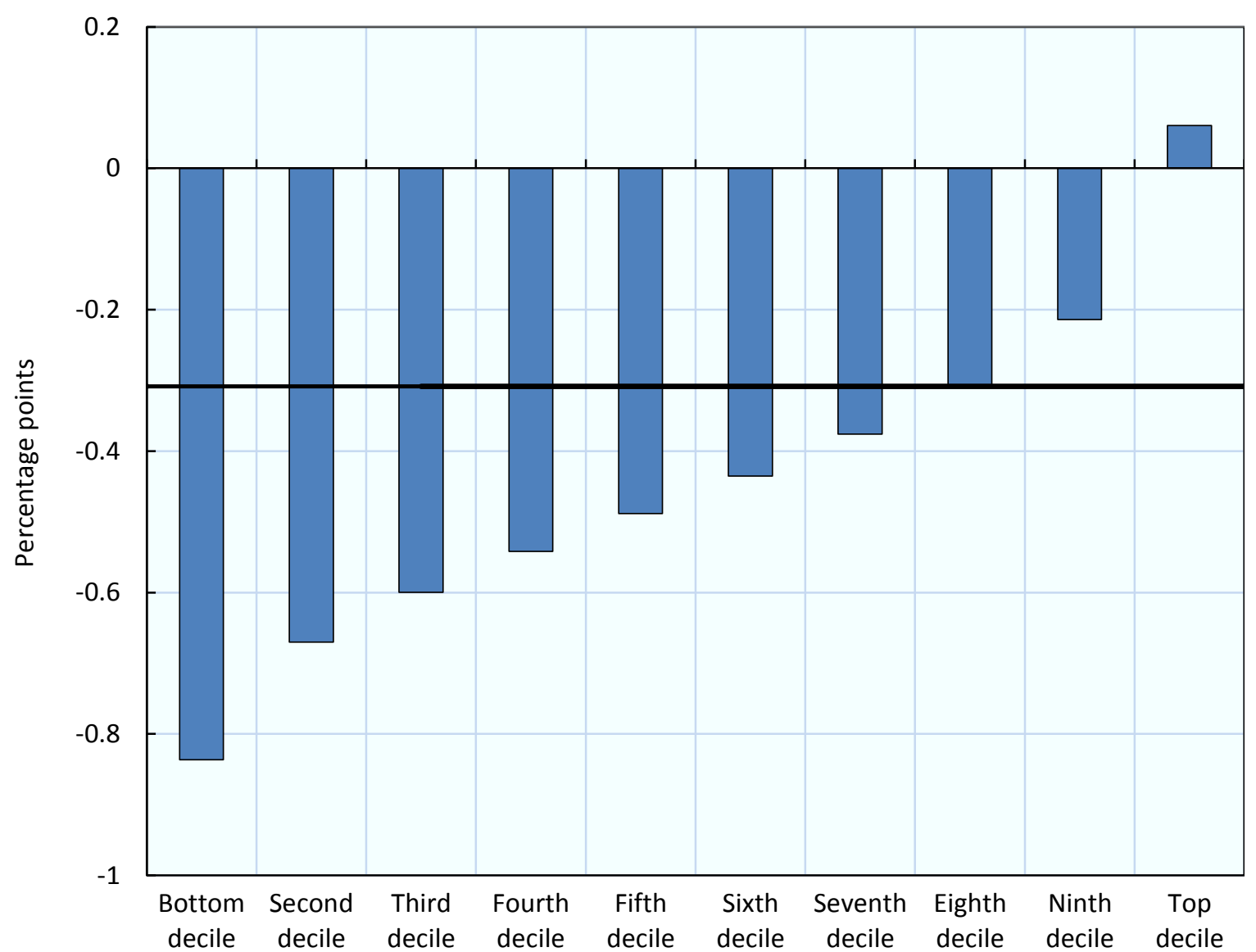

Note: Household income growth is household disposable income growth per capita. Intermediated credit is credit to the non-financial private sector by financial institutions. The horizontal line indicates the change in household income growth for the economy as a whole due to the increase in intermediated credit.

Source: OECD Secretariat calculations using Table 2 (Column 4); Table 6 (Column 4); OECD Income Distribution and Poverty database.

45. A different picture emerges for stock market capitalisation (Figure 11). The association with income growth is again more positive for high-income households, which is an immediate implication of the positive link between stock market capitalisation and the Gini coefficient. However, as stock market capitalisation is positively related with aggregate household income growth, it is only the bottom $30 \%$ who suffer a slowdown of their disposable income growth. An increase in stock market capitalisation by $10 \%$ of GDP is associated with income growth that is 0.2 percentage points lower for the bottom $10 \%$, 0.1 percentage points higher for households in the middle of the income distribution and 0.5 percentage points higher for the top $10 \%$. 
Figure 11. Changes in household income growth for different income deciles from an expansion of stock market capitalisation by $10 \%$ of GDP

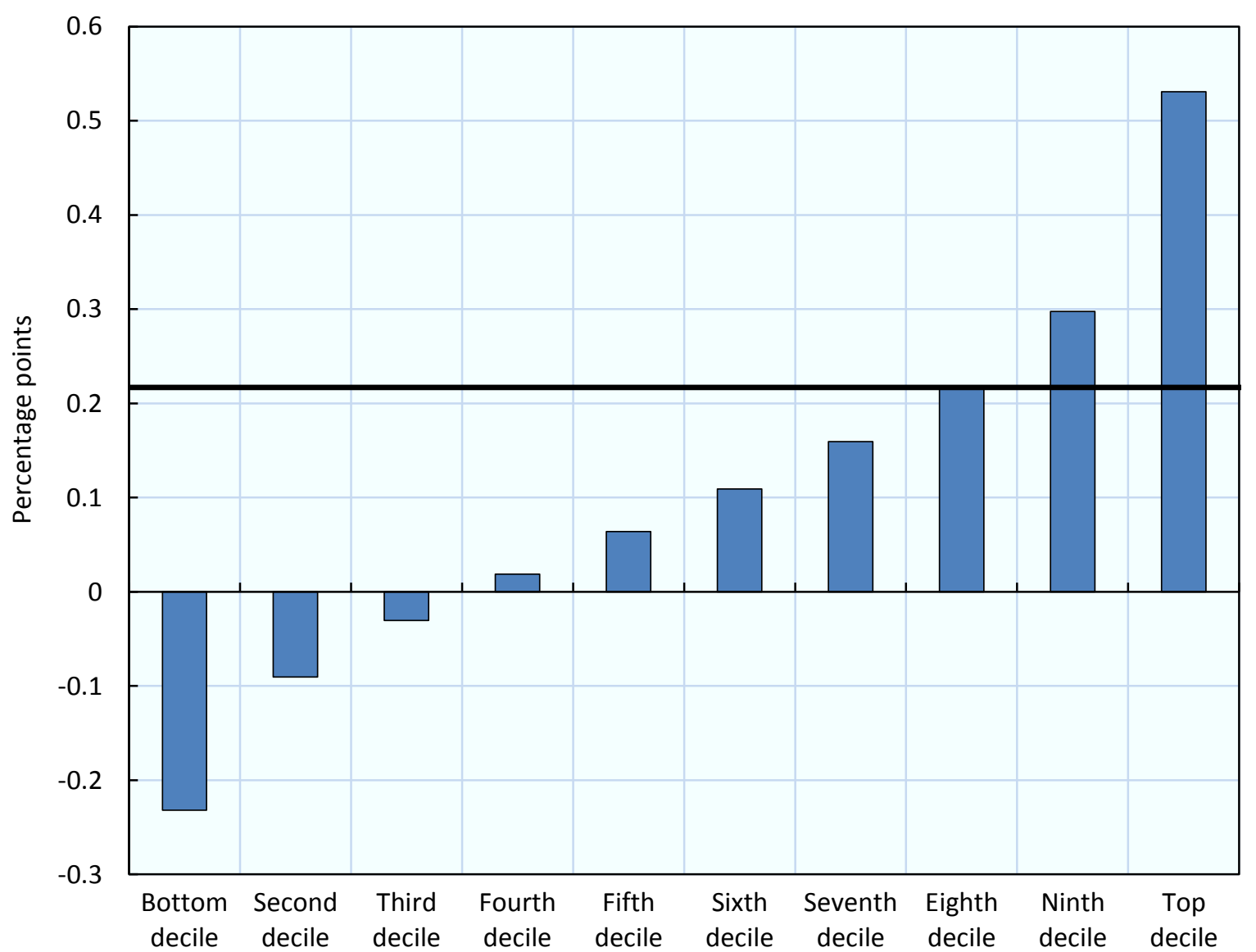

Note: Household income growth is household disposable income growth per capita. Stock market capitalisation is the value of all shares listed in a stock market. The horizontal line indicates the change in household income growth for the economy as a whole due to the increase in stock market capitalisation.

Source: OECD Secretariat calculations using Table 3 (Column 4); Table 7 (Column 4); OECD Income Distribution and Poverty database.

46. The estimates rely on several assumptions; hence, they should be viewed as indicative rather than precise estimates. Nonetheless, the simulations illustrate that financial expansion can have very heterogeneous implications for the income of households at different points in the distribution. They underline that the role of finance for social cohesion can only be understood through a joint analysis of its relationship with both income growth and income inequality. Taken together, the empirical evidence suggests that a large financial sector entails adverse consequences for households at the lower end of the income distribution. For them disposable income growth slows the most; thus, they are the ones whose resources for the consumption of goods and services and whose welfare are most severely affected. By contrast, high-income households are the primary beneficiaries of expanding intermediated credit and stock market capitalisation, as their income growth tends to rise the most.

47. An alternative, more direct, approach to investigate the same question is to regress household disposable income growth for each decile on the two measures of finance. The structure of the data requires two technical adjustments to do so. First, the national accounts are likely to provide a more reliable measure of total disposable income than household surveys. Hence, a decile's level of disposable 
income is calculated by multiplying the decile's share of total disposable income in the OECD Income Distribution and Poverty database by the total disposable income in the OECD Economic Outlook database. Second, the OECD Income Distribution and Poverty database has many missing observations which complicates the calculation of growth rates. In these cases, variables are averaged between the two closest years with data. Relative to the Gini coefficient regressions, this approach has the downside of reducing the sample size by about one half.

48. In line with the earlier approach, more finance (either greater intermediated credit or higher stock market capitalisation) benefits the high more than low and middle earners (Figures 12 and 13). Also, the differences between the income growth at the top and the income growth at the bottom are of comparable order of magnitude. While more finance is associated with increasingly higher income growth across the distribution for intermediated credit, middle-income households seem to miss out on the benefits of stock market expansions. The data therefore suggest the tentative conclusion that the rise in the Gini coefficient associated with higher stock market capitalisation is due to very large income gains at the top. More intermediated credit, however, appears to increase inequality throughout the distribution. Although none of the individual coefficients is statistically significant at conventional levels (except for the top decile with stock market capitalisation which holds at the $10 \%$ level), the decile-to-decile pattern is consistent with an overall negative relationship between finance and equality. The average estimate for stock market capitalisation is nearly identical in both approaches, whereas it changes sign for intermediated credit, which is explained by the drop in the sample from 881 to 148 observations. 
Figure 12. Changes in household income growth for different income deciles from an expansion of intermediated credit by $10 \%$ of GDP (alternative approach)

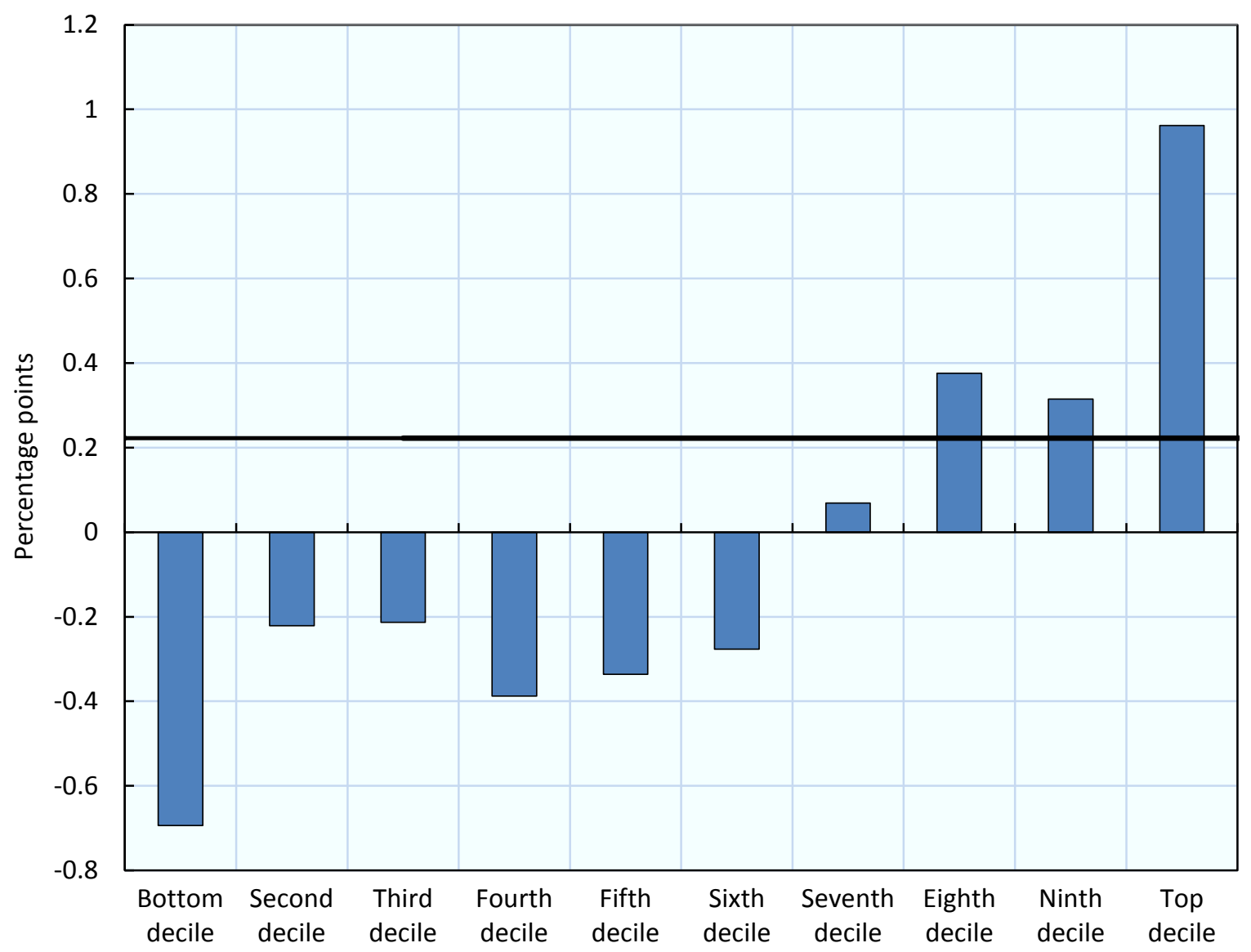

Note: Household income growth is household disposable income growth per capita. Intermediated credit is credit to the non-financial private sector by financial institutions. The horizontal line indicates the change in household income growth for the economy as a whole due to the increase in intermediated credit.

Source: OECD Secretariat calculations using World Bank Global Financial Development database; Bank for International Settlements credit series; Statistics Canada; OECD Income Distribution and Poverty database; OECD Economic Outlook database; R. J. Barro and J. W. Lee (2013), “A New Data Set of Educational Attainment in the World, 1950-2010”, Journal of Development Economics, 104, pp. 184-198; World Bank World Development Indicators database. 
ECO/WKP(2015)42

Figure 13. Changes in household income growth for different income deciles from an expansion of stock market capitalisation by $10 \%$ of GDP (alternative approach)

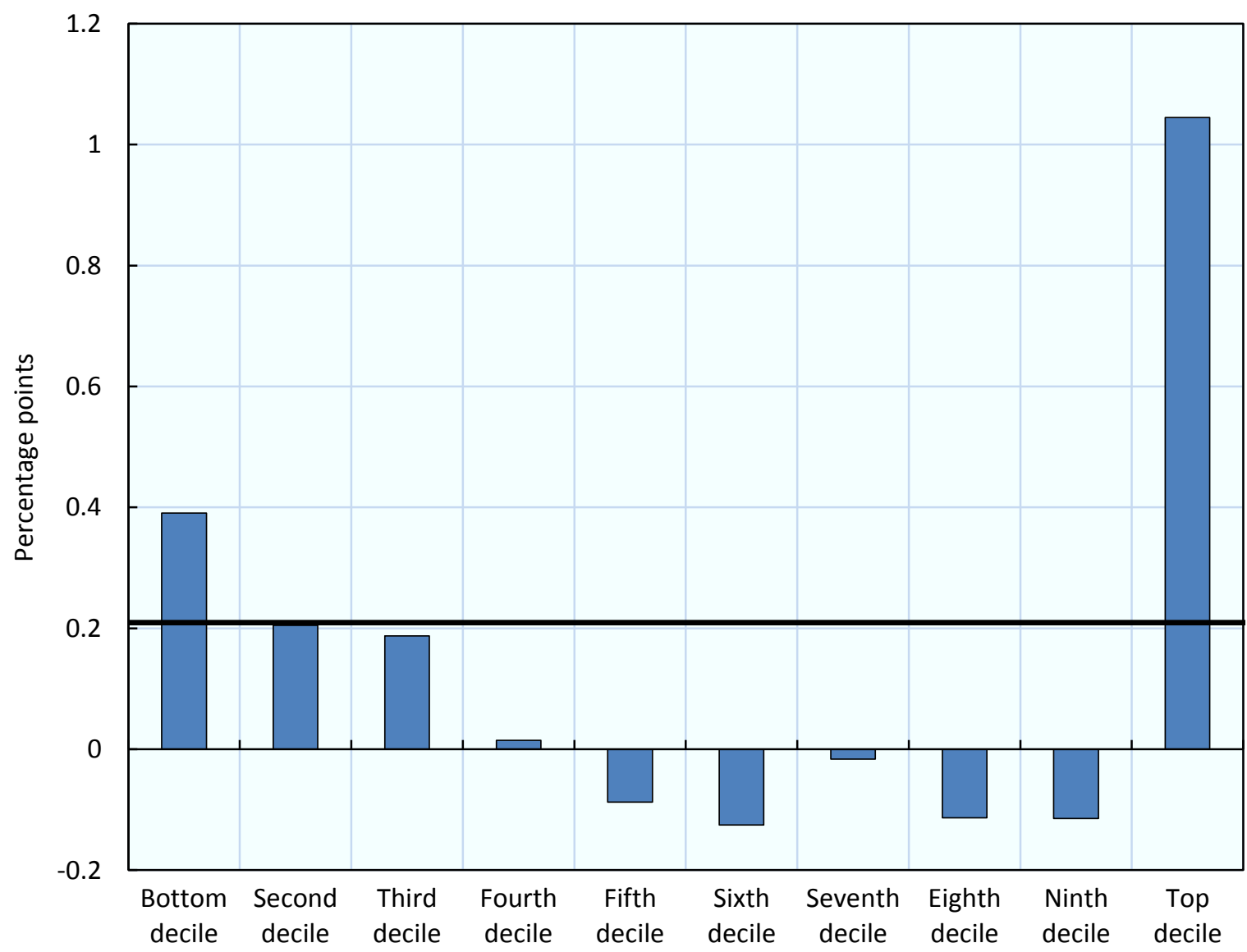

Note: Household income growth is household disposable income growth per capita. Stock market capitalisation is the value of all shares listed in a stock market. The horizontal line indicates the change in household income growth for the economy as a whole due to the increase in stock market capitalisation.

Source: OECD Secretariat calculations using World Bank Global Financial Development database; OECD Income Distribution and Poverty database; OECD Economic Outlook database; R. J. Barro and J. W. Lee (2013), "A New Data Set of Educational Attainment in the World, 1950-2010", Journal of Development Economics, 104, pp. 184-198; World Bank World Development Indicators database. 


\section{APPENDIX 1. DATA SOURCES}

49. The main data sources used in this appendix are: OECD Structural Analysis (STAN) database and OECD Secretariat calculations for the value added of finance; World Bank Global Financial Development database for intermediated credit and stock market capitalisation; OECD Income Distribution and Poverty database for the Gini coefficient and each decile's household disposable income share; OECD Economic Outlook database for the unemployment rate, trade openness, household disposable income growth per capita, aggregate household disposable income and the investment rate; Barro and Lee (2013) for average years of schooling; Laeven and Valencia (2013) for the financial crisis indicator; and World Bank World Development Indicators database for population growth.

50. The value added of finance is based on industry codes $64-66$ following ISIC Rev. 4 classification and therefore includes financial service activities of banks, insurance, pension funds and other financial intermediaries. Insofar as financial activities traditionally associated with banks have over time migrated to other financial corporations, they continue to be accounted for. Intermediated credit is defined as credit to the non-financial private sector by deposit money banks and other financial institutions. Missing values (2 in total) for intermediated credit between years with data have been interpolated.

51. Intermediated credit from the World Bank Global Financial Development database exhibits apparent breaks for Canada and Denmark. The data for Denmark are replaced by the credit series from the Bank for International Settlements (BIS). The difference in their definition is that the data from the World Bank refer to deposit money banks and other financial institutions (Čihák et al., 2012) and the data from the BIS to deposit money banks only (Dembiermont et al., 2013). The data for Canada are replaced by credit data from Statistics Canada. The BIS series was not used for Canada because it does not include credit provided by other financial institutions which makes up a substantial proportion of overall intermediated credit in Canada. The choice of the data source does not affect the estimation results in a material way.

52. The analyses in Section 3 use data from the Eurosystem Household Finance and Consumption Survey and the Bank for International Settlements credit series. 
ECO/WKP(2015)42

\section{BIBLIOGRAPHY}

Abdullah, A., H. Doucouliagos and E. Manning (2014), "Does Education Reduce Income Inequality? A Meta-Regression Analysis”, Journal of Economic Surveys, 29(2), pp. 301-316.

Admati, A. and M. Hellwig (2013), The Bankers' New Clothes: What's Wrong with Banking and What to Do about It, Princeton University Press, Princeton, New Jersey.

Aghion, P. and P. Bolton (1997), "A Theory of Trickle-Down Growth and Development", Review of Economic Studies, 64(2), pp. 151-172.

Angrist, J. D. and J.-S. Pischke (2009), Mostly Harmless Econometrics: An Empiricist's Companion, Princeton University Press, Princeton, New Jersey.

Atkinson, A. B. and S. Morelli (2011), "Economic Crises and Inequality", UNDP Human Development Research Papers, No. 2011/06.

Bahmani-Oskooee, M. and R. Zhang (2015), "On the Impact of Financial Development on Income Distribution: Time-Series Evidence”, Applied Economics, 47(12), pp. 1248-1271.

Barro, R. J. and J. W. Lee (2013), "A New Data Set of Educational Attainment in the World, 1950-2010", Journal of Development Economics, 104, pp. 184-198.

Beck, T. (2012), "The Role of Finance in Economic Development: Benefits, Risks, and Politics", in: D. C. Mueller (ed.), The Oxford Handbook of Capitalism, Oxford University Press, New York.

Beck, T., A. Demirgüç-Kunt and R. Levine (2007), "Finance, Inequality and the Poor", Journal of Economic Growth, 12(1), pp. 27-49.

Beck, T., R. Levine and A. Levkov (2010), "Big Bad Banks? The Winners and Losers from Bank Deregulation in the United States", Journal of Finance, 65(5), pp. 1637-1667.

Bertrand, M. and A. Morse (2014), "Trickle-Down Consumption", University of Chicago and University of California at Berkeley.

Bordo, M. D. and C. M. Meissner (2012), "Does Inequality Lead to a Financial Crisis?", Journal of International Money and Finance, 31(8), pp. 2147-2161.

Braconier, H., G. Nicoletti and B. Westmore (2014), "Policy Challenges for the Next 50 Years", OECD Economic Policy Papers, No. 9.

Braconier, H. and J. Ruiz-Valenzuela (2014), "Gross Earning Inequalities in OECD Countries and Major Non-Member Economies: Determinants and Future Scenarios", OECD Economics Department Working Papers, No. 1139, OECD Publishing, Paris. 
Causa, O., A. de Serres and N. Ruiz (2014), "Can Growth-Enhancing Policies Lift all Boats? An Analysis Based on Household Disposable Incomes", OECD Economics Department Working Papers, No. 1180, OECD Publishing, Paris.

Čihák, M., A. Demirgüç-Kunt, E. Feyen and R. Levine (2012), "Benchmarking Financial Systems around the World", World Bank Policy Research Working Papers, No. 6175.

Claessens, S. and E. Perotti (2007), "Finance and Inequality: Channels and Evidence", Journal of Comparative Economics, 35(4), pp. 748-773.

Clarke, G. R. G, L. C. Xu and H. Zou (2006), "Finance and Income Inequality: What Do the Data Tell Us?”, Southern Economic Journal, 72(3), pp. 578-596.

Coibion, O., Y. Gorodnichenko, M. Kudlyak and J. Mondragon (2014), "Does Greater Inequality Lead to More Household Borrowing? New Evidence from Household Data", NBER Working Papers, No. 19850.

Cournède, B. and O. Denk (2015), "Finance and Economic Growth in OECD and G20 Countries", OECD Economics Department Working Papers, No. 1223, OECD Publishing, Paris.

Cournède, B., O. Denk and P. Hoeller (2015), "Finance and Inclusive Growth", OECD Economic Policy Papers, No. 14, OECD Publishing, Paris.

Delis, M. D., I. Hasan and P. Kazakis (2014), "Bank Regulations and Income Inequality: Empirical Evidence", Review of Finance, 18(5), pp. 1811-1846.

Dembiermont, C., M. Drehmann and S. Muksakunratana (2013), "How Much Does the Private Sector Really Borrow? A New Database for Total Credit to the Private Non-Financial Sector", BIS Quarterly Review, March 2013, pp. 65-81.

Demirgüç-Kunt, A. and R. Levine (2009), "Finance and Inequality: Theory and Evidence", Annual Review of Financial Economics, 1(1), pp. 287-318.

Denk, O. (2015), "Financial Sector Pay and Labour Income Inequality: Evidence from Europe", OECD Economics Department Working Papers, No. 1225, OECD Publishing, Paris.

Denk, O. and A. Cazenave-Lacroutz (2015), "Household Finance and Income Inequality in the Euro Area", OECD Economics Department Working Papers, No. 1226, OECD Publishing, Paris.

Denk, O., S. Schich and B. Cournède (2015), "Why Implicit Bank Debt Guarantees Matter: Some Empirical Evidence", OECD Journal: Financial Market Trends, 107, OECD Publishing, Paris.

Fournier, J.-M. and I. Koske (2012), “The Determinants of Earnings Inequality: Evidence from Quantile Regressions", OECD Journal: Economic Studies, 2012, pp. 7-36, OECD Publishing, Paris.

Galor, O. and O. Moav (2004), "From Physical to Human Capital Accumulation: Inequality and the Process of Development", Review of Economic Studies, 71(4), pp. 1001-1026.

Galor, O. and J. Zeira (1993), "Income Distribution and Macroeconomics", Review of Economic Studies, 60(1), pp. 35-52. 
Gimet, C. and T. Lagoarde-Segot (2011), "A Closer Look at Financial Development and Income Distribution”, Journal of Banking \& Finance, 35(7), pp. 1698-1713.

Greenwood, J. and B. Jovanovic (1990), "Financial Development, Growth, and the Distribution of Income”, Journal of Political Economy, 98(5), pp. 1076-1107.

Gu, X. and B. Huang (2014), "Does Inequality Lead to a Financial Crisis? Revisited", Review of Development Economics, 18(3), pp. 502-516.

Jauch, S. and S. Watzka (2012), "Financial Development and Income Inequality: A Panel Data Approach", CESifo Working Papers, No. 3687.

Korinek, A. and J. Kreamer (2014), “The Redistributive Effects of Financial Deregulation", Journal of Monetary Economics, 68(S), pp. 55-67.

Kumhof, M., R. Rancière and P. Winant (2015), "Inequality, Leverage and Crises", American Economic Review, 105(3), pp. 1217-1245.

Laeven, L. and F. Valencia (2013), "Systemic Banking Crises Database”, IMF Economic Review, 61(2), pp. 225-270.

Liang, K.-Y. and S. L. Zeger (1986), "Longitudinal Data Analysis Using Generalized Linear Models", Biometrika, 73(1), pp. 13-22.

OECD (2008), Growing Unequal? Income Distribution and Poverty in OECD Countries, OECD Publishing, Paris.

OECD (2011), Divided We Stand: Why Inequality Keeps Rising, OECD Publishing, Paris.

OECD (2013), Crisis Squeezes Income and Puts Pressure on Inequality and Poverty, OECD Publishing, Paris.

OECD (2015), In It Together: Why Less Inequality Benefits All, OECD Publishing, Paris.

Piketty, T. (2014), Capital in the Twenty-First Century, Harvard University Press, Cambridge, MA.

Rajan, R. G. (2010), Fault Lines: How Hidden Fractures Still Threaten the World Economy, Harper Collins, New York.

Ramskogler, P. (2015), "Tracing the Origins of the Financial Crisis", OECD Journal: Financial Market Trends, 107, OECD Publishing, Paris.

Schich, S., M. Bijlsma and R. Mocking (2014), "Improving the Monitoring of the Value of Implicit Guarantees for Bank Debt", OECD Journal: Financial Market Trends, 106, OECD Publishing, Paris.

Schich, S. and S. Lindh (2012), "Implicit Guarantees for Bank Debt: Where Do We Stand?", OECD Journal: Financial Market Trends, 102, OECD Publishing, Paris.

Ueda, K. and B. Weder di Mauro (2013), "Quantifying Structural Subsidy Values for Systemically Important Financial Institutions”, Journal of Banking \& Finance, 37(10), pp. 3830-3842. 


\section{WORKING PAPERS}

The full series of Economics Department Working Papers can be consulted at www.oecd.org/eco/workingpapers.

1223. Finance and economic growth in OECD and G20 countries

(June 2015) by Boris Cournède and Oliver Denk

1222. What impedes household investment in energy efficiency and renewable energy?

(May 2015) by Nadia Ameli and Nicola Brandt

1221. Recent trends in productivity in China - shift-share analysis of labour productivity growth and the evolution of the productivity gap

(May 2015) by Margit Molnar and Thomas Chalaux

1220. Assessing China's skills gap and inequalities in education

(May 2015) by Margit Molnar, Boqing Wang and Ruidong Gao

1219. Providing the right skills to all in China - from "made in China" to "created in China"

(May 2015) by Margit Molnar and Vincent Koen

1218. Agricultural reforms and bridging the gap for rural China

(May 2015) by Ben Westmore

1217. A snapshot of China's service sector

(May 2015) by Margit Molnar and Wei Wang

1216. Does the post-crisis weakness of global trade solely reflect weak demand?

(May 2015) by Patrice Ollivaud and Cyrille Schwellnus

1215. Estonia: raising productivity and benefitting more from openness

(May 2015) by Andreas Kappeler

1214. Estonia: making the most of human capital

(May 2015) by Andrés Fuentes Hutfilter

1213. The Czech labour market: documenting structural change and remaining challenges

(May 2015) by Sónia Araújo and Petr Malecek

1212. Reforming the Slovak public sector

(April 2015) by Lilas Demmou and Robert Price

1211. Spurring growth in lagging regions in the Slovak Republic

(April 2015) by Lilas Demmou, Gabriel Machlica, Martin Haluš and Robert Menkyna

1210. Skill mismatch and public policy in OECD countries

(April 2015) by Müge Adalet McGowan and Dan Andrews

1209. Labour market mismatch and labour productivity: evidence from PIAAC data

(April 2015) by Müge Adalet McGowan and Dan Andrews 
ECO/WKP(2015)42

1208. Maintaining an efficient and equitable housing market in Belgium (April 2015) by Sanne Zwart

1207. Determinants of the low female labour force participation in India (April 2015) by Piritta Sorsa, Jan Mares, Mathilde Didier, Caio Guimaraes, Marie Rabate, Gen Tang and Annamaria Tuske

1206. Strengthening skill use and school-to-work transitions in the Czech Republic (April 2015) by Sónia Araújo and Petr Malecek

1205. Reforming the tax on immovable property: taking care of the unloved (April 2015) by Hansjörg Blöchliger

1204. Taxation and investment in Colombia (April 2015) by Sarah Perret and Bert Brys

1203. Efficiency and contestability in the Colombian banking system (April 2015) by Christian Daude and Julien Pascal

1202. Fiscal decentralisation in Colombia: new evidence regarding sustainability, risk sharing and "fiscal fatigue"

(April 2015) by Guillaume Bousquet, Christian Daude and Christine de la Maisonneuve

1201. Effects of economic policies on microeconomic stability

(April 2015) by Boris Cournède, Paula Garda and Volker Ziemann

1200. The 2013 update of the OECD's database on product market regulation - policy insights for $O E C D$ and non-OECD countries

(April 2015) by Isabell Koske, Isabelle Wanner, Rosamaria Bitetti and Omar Barbiero

1199. Improving taxes and transfers in Australia

(April 2015) by Philip Hemmings and Annamaria Tuske

1198. Federal-state relations in Australia

(April 2015) by Vassiliki Koutsogeorgopoulou and Annamaria Tuske

1197. Sharing the fruits of growth with all Mexicans

(April 2015) by Eduardo Olaberriá and Valéry Dugain

1196. What makes Mexicans happy?

(April 2015) by Valéry Dugain and Eduardo Olaberriá

1195. Improving the labour market integration of immigrants in Belgium (March 2015) by Álvaro Pina, Vincent Corluy and Gerlinde Verbist

1194. Raising the potential of the domestically oriented sector in Germany (March 2015) by André Eid and Andrés Hutfilter

1193. Improving transport infrastructure in Russia

(March 2015) by Alexander Kolik, Artur Radziwill and Natalia Turdyeva 